\title{
Do Stronger Intellectual Property Rights Increase International Technology Transfer? Empirical Evidence from U.S. Firm-Level Panel Data ${ }^{1}$
}

\author{
Lee G. Branstetter \\ Columbia Business School and NBER \\ Raymond Fisman \\ Columbia Business School and NBER \\ C. Fritz Foley \\ University of Michigan
}

\footnotetext{
1 The statistical analysis of firm-level data on U.S. multinational companies was conducted at the International Investment Division, Bureau of Economic Analysis, U.S. Department of Commerce under arrangements that maintain legal confidentiality requirements. The views expressed are those of the authors and do not reflect official positions of the U.S. Department of Commerce. The authors thank Vincent Leung, Changxiu Li, Grace Lin, and Yoshiaki Ogura for excellent research assistance, and we are grateful to the Columbia Business School Finance and Economics Division, the Chazen Institute, the NBER, the National Science Foundation, and the World Bank Research Group for financial support. We also thank (without implicating) Adam Jaffe, Daniel Johnson, Tarun Khanna, Joshua Lerner, Jim Levinsohn, Jim Markusen, Keith Maskus, Joanne Oxley, Krishna Palepu, Michael Riordan, Kamal Saggi, Manuel Trajtenberg, and workshop participants at Columbia, the University of Michigan, Yale, Harvard Business School, and the NBER for helpful comments.
} 


\begin{abstract}
One of the alleged benefits of the recent global movement to strengthen intellectual property rights (IPR) is that such reforms accelerate transfers of technology between countries. This paper examines how technology transfer among U.S. multinational firms changes in response to a series of IPR reforms undertaken by 12 countries over the 198299 period. Analysis of detailed firm-level data reveals that royalty payments for intangibles transferred to affiliates increase at the time of reforms, as do affiliate research and development $(R \& D)$ expenditures and total levels of foreign patent applications. Increases in royalty payments and $\mathrm{R} \& \mathrm{D}$ expenditures are more than $20 \%$ larger among affiliates of parent companies that use U.S. patents more extensively prior to reform and therefore are expected to value IPR reform most.
\end{abstract}

Lee G. Branstetter

Columbia Business School and NBER

Uris 815

3022 Broadway

New York, NY 10027

TEL 212-854-2722

1gb2001@columbia.edu

Raymond Fisman

Columbia Business School and NBER

Uris 823

3022 Broadway

New York, NY 10027

TEL 212-854-9157

rf250@columbia.edu

C. Fritz Foley

University of Michigan Business School

701 Tappan St.

Ann Arbor, MI 48109

TEL (734) 763-1436

ffoley@umich.edu 


\section{Non-technical summary}

The Agreement on Trade-Related Aspects of Intellectual Property Rights (TRIPs) requires a number of countries to strengthen their patent and other intellectual property rights (IPR) systems. Even though policy makers have committed to significant reforms, the implementation of this agreement remains contentious. On one side, many policymakers believe that this mandated policy change will work against their national economic interests, transferring rents to multinational corporate patent holders headquartered in the world's most advanced countries, especially the United States. Advocates for strong IPR counter that strengthening IPR will accelerate the transfer of technology between countries, ensuring a relatively equal distribution of gains from this policy change.

This paper uses affiliate-level data on U.S. multinational firms and aggregate patent data to test if legal reforms that strengthen IPR increase the transfer of technology by multinationals to reforming countries. Throughout the 1980s and 1990s, a number of countries undertook reforms of their intellectual property systems. Analysis of data from the Bureau of Economic Analysis's survey of U.S. multinational firms reveals evidence of an increase in technology transfer from parent firms to affiliates located in IPR-reforming countries. More precisely, royalty payments for the use or sale of intangible assets made by affiliates to parent firms increase in the wake of strengthened IPR regimes. This increase is concentrated among the affiliates of firms that make more extensive use of U.S. patents prior to the reforms. In contrast, the evidence of an increase in technology licensing to unaffiliated parties is weaker and is concentrated in those firms that did not possess affiliates in the reforming countries prior to the implementation of reforms.

The view that IPR reform results in an increase in technology transfer among U.S. multinationals is strengthened by the fact that R\&D spending by affiliates - traditionally viewed as a complement to technology imports from the parent - increases after IPR reform. Examination of international trends in patent applications also suggests that at least one component of the observable increase in licensing flows is associated with the introduction of new technology in the wake of patent reform. Both the level and rate of change of nonresident patenting increase in the post-reform period. Consistent with earlier work, the results indicate no corresponding reaction in resident patent filings. Interviews with practitioners confirm that the strength of the local IPR regime is one of the critical factors reviewed by U.S.-based multinationals in determining the scope and level of local affiliate operations. Collectively, our results provide evidence that improvements in IPR result in real increases in technology transfers by multinational enterprises. 


\section{Introduction}

The Agreement on Trade-Related Aspects of Intellectual Property Rights (TRIPs) requires a number of countries to strengthen their patent and other intellectual property rights (IPR) systems. ${ }^{2}$ Even though policymakers have committed to significant reforms, the implementation of this agreement remains contentious. On one side, many policymakers believe that this mandated policy change will work against their national economic interests, transferring rents to multinational corporate patent holders headquartered in the world's most advanced countries, especially the United States. ${ }^{3}$ Advocates for strong IPR counter that strengthening IPR will induce more innovation, thereby fostering more rapid economic growth. These advocates also believe that a strengthening of IPR will accelerate the transfer of technology between countries, ensuring a relatively equal distribution of gains from this policy change.

Despite this heated policy debate, the economics literature has only started to confront alternative viewpoints with facts. While theoretical work provides valuable frameworks that detail the circumstances under which IPR enhances and reduces welfare, many hypothesized effects of IPR have not been held up to empirical scrutiny. This paper uses affiliate-level data on U.S. multinational firms and aggregate patent data to test whether legal reforms that strengthen IPR increase the transfer of technology by multinationals to reforming countries. Throughout the 1980s and 1990s, a number of countries undertook reforms of their intellectual property systems. Analysis of data from the Bureau of Economic Analysis's survey of U.S. multinational firms reveals evidence

\footnotetext{
2 Implementation of the terms of this agreement is ongoing. Some developing countries have until 2016 to fully comply.

3 For a more academic treatment of some of these claims see Lanjouw (1997) and McCalman (2001).
} 
of an increase in technology transfer from parent firms to affiliates located in IPRreforming countries. More precisely, royalty payments for the use or sale of intangible assets made by affiliates to parent firms increase in the wake of strengthened IPR regimes. This increase is concentrated among the affiliates of firms that make more extensive use of U.S. patents prior to the reforms. In contrast, the evidence of an increase in technology licensing to unaffiliated parties is weaker and is concentrated in those firms that did not possess affiliates in the reforming countries prior to the implementation of reforms.

The view that IPR reform results in an increase in technology transfer among U.S. multinationals is strengthened by the fact that research and development (R\&D) spending by affiliates - traditionally viewed as a complement to technology imports from the parent - increases after IPR reform. Examination of international trends in patent applications also suggests that at least one component of the observable increase in licensing flows is associated with the introduction of new technology in the wake of patent reform. Both the level and rate of change of nonresident patenting increase in the post-reform period. Consistent with earlier work, the results indicate no corresponding reaction in resident patent filings. Interviews with practitioners confirm that the strength of the local IPR regime is one of the critical factors reviewed by U.S.-based multinationals in determining the scope and level of local affiliate operations. Collectively, our results provide evidence that improvements in IPR result in real increases in technology transfers by multinational enterprises.

The rest of this paper is structured as follows: Section 2 provides a brief overview of the extant literature on IPR and international economic activity and puts forth the 
hypotheses we test. Section 3 describes the data, and Section 4 discusses the results.

Section 5 concludes.

\section{Intellectual Property Rights and Technology Transfers}

\subsection{Prior Literature}

Previous work on the role of IPR in promoting innovation and growth in the global economy falls into three main categories: studies of the responsiveness of domestic innovation to IPR, studies of the impact of changing IPR in the developing world on global welfare, and studies of the responsiveness of types of international economic activity like trade or foreign direct investment (FDI) to IPR.

The first of these streams of research is based largely in the industrial organization literature and examines the role of IPR in promoting innovation. This work generally considers reactions to specific changes in the IPR regime of a single country (see, for example, Scherer and Weisburst (1995); Bessen and Maskin (2000); or Sakakibara and Branstetter (2001)). A large number of these studies find that a strengthening of IPR results in little or no measured increase in domestic innovation. ${ }^{4}$

Lerner $(2001,2002)$ avoids criticisms related to the generality of single country studies by analyzing the impact of all significant patent reforms over the last 150 years in a sample of 60 countries. His findings confirm that reforms have few positive effects on patent applications by entities based in the country undertaking the policy change.

Although Lerner's work does not consider the effects of reforms on technology transfer, he finds that foreign applicants do respond to these changes by increasing their patenting

\footnotetext{
4 Cockburn and Lanjouw (2001) attempt to discern the impact of TRIPs on the composition of pharmaceutical research and find, at best, mixed evidence of a modest impact.
} 
after reforms. ${ }^{5}$ This finding suggests that one of the primary mechanisms by which economies may benefit from IPR reform is through obtaining larger technology flows from multinationals, the issue that we examine in this paper.

A second stream of research, most of it theoretical, has sought to examine the global welfare implications of patent reform in developing countries. The pioneering work of Helpman (1993) demonstrated that strengthening IPR could actually lower global welfare. In Helpman's framework, human resources in the North are divided between generating new products (innovation) and the manufacture of existing products (production). Over time, the production of mature products is transferred to Southern firms through a process of imitation of Northern products. By raising the costs of Southern imitation, stronger IPR in the South slows down this process of transfer of production to the South. Because goods continue to be produced in the North, the wage of Northern labor is bid up - and this raises the cost of R\&D, slowing the rate at which new products are generated. Because the pace of innovation is reduced, global welfare declines.

Lai (1998) introduced the possibility of foreign direct investment into a model similar to that of Helpman (1993). ${ }^{6}$ Lai showed that, in a model with FDI, stronger IPR could actually accelerate the transfer of production to the South - but the means of this transfer would be through FDI rather than imitation by indigenous Southern firms. Glass and Saggi (2002) challenge Lai's predictions. In their model, the global welfare impact

\footnotetext{
5 Related recent theoretical work by Grossman and Lai (2002) emphasizes that in a global economy, the strengthening of a domestic patent system may have little impact. This is particularly true if the world's largest economies already have strong patent systems under which firms based in developing countries can apply for patent protection. Going further, Grossman and Lai demonstrate that international harmonization of patent protection is neither necessary nor sufficient for global efficiency.

${ }^{6}$ In Helpman's original formulation, the only way production of a good was transferred to the South was through imitation by indigenous Southern firms.
} 
of IPR strengthening in the South also depends on its impact on FDI. They show a range of conditions and parameter values under which stronger IPR in the South reduces FDI, and they conclude that the global welfare impact of stronger IPR could still be negative. Therefore, empirical facts concerning the effects of IPR reform on transfers of technology from multinationals are crucial to the assessment of the welfare consequences of reform. We analyze these effects. It is worth noting that we distinguish between deliberate technology transfers by firms and other forms of technological spillovers and focus on the former. ${ }^{7}$

Empirical work that directly addresses the welfare impact of changes in IPR has lagged behind theory. Perhaps the best-known empirical work to date that explicitly seeks to measure welfare impact is that of McCalman. Building on the work of Eaton and Kortum (1996), McCalman (2001) estimates a structural model of innovation and technology transfer to infer the implications of the TRIPs agreement. His calculations suggest that patent harmonization would result in large transfers between countries and in particularly large benefits for the U.S. As he acknowledges, this study does not include any accounting of the benefits that might accrue from a higher rate of innovation, nor does it factor in the potential for an acceleration of technology transfer in response to a strengthening of IPR.

Finally, there is a literature that analyzes the cross-sectional relationship between IPR and measures of international trade and investment. In looking at bilateral trade patterns, Maskus and Penubarti (1995) found a strong positive effect of IPR on imports. Smith (1999) reports results that are consistent with a role for IPR in encouraging U.S. exports.

\footnotetext{
${ }^{7}$ For recent work on other forms of technological spillovers, see Keller (2002) and Branstetter (2000).
} 
The evidence of the effect of IPR on FDI is less clear. Maskus and Eby-Konan (1994) find no effect of IPR measures on FDI. Maskus (1998), however, points out that studies that consider FDI in isolation may not be conclusive because investment is only one part of the broader set of decisions that a multinational firm makes in entering a market. He reports regressions that are consistent with a positive effect of IPR on FDI, but only for more developed countries. ${ }^{8}$ In principle, multinationals can transfer technology to developing countries even without undertaking FDI. Yang and Maskus (2000) examine the effect of improved IPR regimes on arm's length licensing by U.S. Multinational Enterprise's (MNE) and report a strong positive relationship. ${ }^{9}$

While these papers are suggestive of some interesting patterns, they all suffer from the usual problems that affect cross-country regressions. The measures of IPR utilized do not generally take into account the effectiveness of enforcement, they are highly correlated with other important country characteristics, and they have limited time-series variation. Since FDI data are typically not disaggregated, even by industry, it has also not been possible to look at the impact of IPR reform on the composition of multinational activity. ${ }^{10}$ The data and methodology employed in our paper allow for a more convincing examination of the impact of IPR on technology transfers.

\footnotetext{
8 Lee and Mansfield (1996) also study the impact of IPR on FDI, taking a cross-sectional approach.

${ }^{9}$ Smith (2001) also examines the impact of IPR on licensing and FDI, obtaining results with the licensing variable that are consistent with those of Yang and Maskus.

${ }^{10}$ One recent exception is Smarzynska (2000), who examines the composition of FDI in Eastern Europe in the 1990s and relates this composition to differences across countries in IPR regimes. Because this study focuses on a small number of countries in a single region of the developing world, natural questions arise about the extent to which these findings can be generalized outside their regional context.
} 


\subsection{Hypotheses and Empirical Specifications}

One of the potential benefits of stronger intellectual property rights is that such protections may induce foreign firms to produce and sell technologically advanced goods in the host country. The previous literature, as well as basic intuition, suggests that if IPR regime shifts have a material impact on true intellectual property protection, then there should be an increase in the value of technology flows from parents to affiliates following regime changes. This hypothesis is formally derived in a simple theoretical model laid out in Appendix B and examined with regressions of the following form:

$$
\begin{aligned}
& \text { Transfer }_{i l t}=\alpha_{0}+\alpha_{i l}+\alpha_{t}+\beta_{0} y_{j t}+\beta_{1} P_{i t}+\beta_{2} H_{j t}+\beta_{3} A_{i l t}+ \\
& \beta_{4} R_{j t}+\beta_{5} R_{j t} * \text { Pat }_{i l}+\varepsilon_{i l t}
\end{aligned}
$$

where $l$ indexes the individual affiliate, $i$ the affiliate's parent firm, $j$ the affiliate's host country, and $t$ the year. The dependent variable measures the volume of intrafirm royalty payments for intangible assets - the proxy for technology transfer. The key variable of interest is $\mathrm{R}_{j t}$, the post reform dummy variable, equal to one in the year of and years following patent reform in country j. ${ }^{11}$ The specification includes time-invariant fixed effects for the affiliate $\left(\alpha_{i l}\right)$, year fixed effects for the entire sample $\left(\alpha_{t}\right)$, and countryspecific time trends. ${ }^{12}$ As a consequence, identification of the effect of reforms comes from differences in the timing of reforms.

A number of other controls are also included in the specification. $P_{i t}$ is a vector of time-varying characteristics of the parent firm, including measures of size and R\&D

\footnotetext{
11 As a robustness check, we also estimated a version of (1) in which patent reform was parameterized as a series of dummy variables corresponding to lags of set length before and after patent reform. These results suggest no statistically significant change prior to reform, but a steady, statistically significant increase in licensing after reform.

${ }^{12}$ To be precise, we include dummy variables for each affiliate-parent pair. Some affiliates are sold to other multinationals over our sample period. When an affiliate is acquired by a new parent, we effectively treat it as a different affiliate. This treatment of the data precludes the need for separate parent firm fixed effects.
} 
investment. These variables control for the natural tendency for technology transfers from a parent to change as these state variables change over time. $H_{j t}$ is a set of timevarying characteristics of the host country, including the log of GDP per capita and an indicator of whether the host country imposes restrictions on inward FDI. Also among the country level controls are two tax variables that capture how tax considerations affect the incentives of firms in setting the value of intangibles. These are the difference between the host country corporate income tax rate and the U.S. corporate income tax rate and the withholding tax rate charged on royalty payments by the host country. ${ }^{13}$ Finally, $A_{i l t}$ is a vector of time-varying characteristics of individual affiliates, including the $\log$ of affiliate sales. ${ }^{14}$

The increase in the value of technology flows from parent firms to affiliates should be largest for firms that value patent protection the most. In order to study the differential effects of patent reforms across firms, affiliates are split into two groups according to the extent to which parents of affiliates use U.S. patents prior to the reform. Those affiliates of parents that, over the four years prior to a particular reform, average at least as many U.S. patent applications as the parent of the median affiliate in the reforming country over the same period are assigned a high patent use dummy, Pat ${ }_{i l}$, equal to one. For other affiliates that have parents that can be matched to the NBER

\footnotetext{
${ }^{13}$ Inclusion of variables on tax rates enables us to control, at least in part, for the potential impact of transfer pricing on our measures of technology transfer. Measures of international economic activity generally find that distance is an important factor in explaining the distribution of trade and investment across countries, but geographic distance between the United States and each host country will be absorbed into the host country dummy variable.

${ }^{14}$ We recognize that some of the regressors are potentially endogenous, but our aim here is not to estimate structural coefficients but rather to obtain a general sense of how measures of affiliate performance are conditionally correlated with IPR reform. Regressors that may pose a problem are excluded from some specifications.
} 
patent database, Pat $_{i l}$ equals zero. ${ }^{15}$ This dummy variable is interacted with the post reform dummy variable.

Changes in the value of licensing payments could reflect changes in the volume of technology transferred or merely changes in the price charged for that technology. Analyzing changes in the $R \& D$ expenditures of affiliates is helpful in distinguishing between these two possibilities. There is a considerable body of work that details the relationship between affiliate and parent-firm R\&D. ${ }^{16}$ It is clear that U.S.-based multinationals undertake basic and applied research abroad, as well as product development. However, to the extent that it is done outside the United States, research tends to be concentrated in other developed countries, such as Germany, where the local scientific and engineering community is highly accomplished and the infrastructure for frontier research is well-developed. R\&D conducted by affiliates in developing countries, which account for most of the countries in our sample, tends to be focused on the modification of parent firm technology for local markets. ${ }^{17}$ The literature review presented in Kuemmerle (1999) makes the point that a number of studies suggest that the co-location of R\&D with foreign manufacturing facilitates the "transfer of knowledge and prototypes from the firm's home location to actual manufacturing." ${ }^{18}$ Viewed in this light, affiliate $R \& D$ and technology transfers from the parent can be considered complements. Given this complementary relationship, IPR reform should also prompt an increase in $R \& D$ spending.

\footnotetext{
${ }^{15}$ Alternative ways of specifying Pat $_{i l}$ yield similar results. A four year window is used in these calculations because the sample begins in 1982 and the first reform occurs in 1986.

16 For an early study on this topic, see Mansfield, Teece, and Romeo (1979). Kuemmerle (1999) provides an excellent survey of the literature as of 1999.

17 Mansfield, Teece, and Romeo (1979) were perhaps the first scholars to make this observation.

18 Studies by Bartlett and Ghoshal (1990), Hakanson (1990), Vernon (1966), Fors (1997), Clark and Fujimoto (1991), Hayes and Wheelwright (1988), Nonaka and Takeuchi (1995), and von Hippel (1988) generally support this view.
} 
To test if this is the case, variations of the basic specification are used to analyze affiliate R\&D. These specifications take the form:

$$
\begin{aligned}
& R \& D_{i l t}=\alpha_{0}+\alpha_{i l}+\alpha_{t}+\beta_{0} y_{j t}+\beta_{1} P_{i t}+\beta_{2} H_{j t}+\beta_{3} A_{i l t}+\beta_{4} R_{j t}+ \\
& \beta_{5} R_{j t} * \mathrm{Pat}_{i l}+\varepsilon_{i l t}
\end{aligned}
$$

The dependent variable measures the level of R\&D spending conducted by affiliate $l$ of parent $i$ in year $t$. The right hand side variables remain as they were in specification (1).

Changes in technology transfer are not constrained to take place between parents and their affiliates. Firms also license intangible assets to arm's length parties. The prior literature, intuition, and the formal model laid out in Appendix B predict that this type of licensing may also increase after IPR reform. Equation (1) above can be slightly altered to study these flows:

$$
\text { License }_{i j t}=\alpha_{0}+\alpha_{i j}+\alpha_{t}+\beta_{0} y_{j t}+\beta_{1} H_{j t}+\beta_{2} R_{j t}+\varepsilon_{i j t}
$$

Here, the dependent variable measures royalty payments received by parent firm $i$ from unaffiliated parties in country $j$ in year $t$. Unfortunately, the surveys that collect these data do not record detailed information on the characteristics of licensee or licensor firms. As a result, firm/country fixed effects $\left(\alpha_{i j}\right)$ take the place of affiliate fixed effects, and it is not possible to control for characteristics of firms that pay or receive licensing fees. Other right hand side variables include a vector of host country characteristics $\left(H_{j t}\right)$, and host-country specific time trends $\left(y_{j t}\right)$.

If multinationals do change the volume of technology transferred in a sustained manner and if these changes are a consequence of stronger IPR, then this should be reflected in the data on foreign patenting in reforming countries. In the absence of a truly international patent system, firms have to seek patent grants in each country in which 
they operate. Obtaining these patent grants is not costless. One could view obtaining a patent grant as equivalent to purchasing an option to deploy a particular technology with local legal protection. A foreign multinational has little incentive to go through the time and trouble of preparing and filing patent applications in a jurisdiction where patent rights are weak. ${ }^{19}$ When IPR reform occurs and patent laws are strengthened, the multinational may have the incentive to file patents for all of the technologies currently employed in the jurisdiction. This would imply a temporary increase in foreign patent filing that would eventually fall off as firms completed protecting the portfolio of technologies currently being used in the country in question. ${ }^{20}$ However, multinationals may be induced by the patent regime changes to transfer new technologies into the jurisdiction. This predicts not only a one-time shift in the level of patent filings but also increased growth in foreign patenting over time in the reformed jurisdictions after reforms.

Specifications that test these predictions take the form:

$$
\text { Patent }_{j t}=\alpha_{0}+\alpha_{j}+\alpha_{t}+\beta_{0} y_{j t}+\beta_{1} H_{j t}+\beta_{2} R_{j t}+\beta_{3} R_{j t} * y_{j t}+\varepsilon_{j t}
$$

Here the dependent variable measures the number of patents filed by domestic or foreign applicants in country $\mathrm{j}$ in year $\mathrm{t}$. We estimate (4) separately for domestic and foreign patenting in the countries that underwent IPR reform. Patent applications in year $t$ are a function of country $\left(\alpha_{j}\right)$ and year $\left(\alpha_{t}\right)$ fixed effects as well as host country

\footnotetext{
19 Interviews with multinational managers confirmed the historically selective nature of U.S. firms' foreign patenting.

20 Most countries require inventors to seek local patent protection for their inventions within one year of filing a patent in any country - otherwise, the inventor forfeits the possibility of patent protection in that country. In theory, firms could circumvent this restriction by slightly altering the technical contents of their patent applications, effectively presenting applications for "old" technology as if it were new.

Conversations with multinational IPR managers suggested that, while this sometimes happens, it is difficult to do this in practice when the local patent system is competently and professionally managed.
} 
characteristics $\left(H_{j t}\right)$. This specification allows patent reform to affect not only the level of patenting but also its growth rate over time, which is reflected in the inclusion of an interaction term of the reform dummy and the time trend.

\section{Data Sources}

\subsection{Data from BEA Surveys}

Data on U.S. multinational firms comes from the U.S. Bureau of Economic Analysis (BEA) annual Survey of U.S. Direct Investment Abroad and the quarterly Balance of Payments Survey. ${ }^{21}$ The survey forms concerning MNE activity capture extensive information on measures of parent and affiliate operating activity like levels of sales and R\&D expenditures. MNEs must also report the value of royalties paid by affiliates to parents for the sale or use of intangible property. American tax law requires that foreign affiliates make these payments. The reported figures on the value of intangible property transferred include an amalgam of technology licensing fees, franchise fees, fees for the use of trademarks, etc. However, the aggregate data indicate that intangible property transfers are overwhelmingly dominated by licensing of industrial products and processes. ${ }^{22}$

Depending on the particular circumstances, firms may have an incentive to misrepresent the value of a technology transfer to avoid taxes even though they are

\footnotetext{
${ }^{21}$ The forms firms are required to complete vary depending on the year, size of the affiliate, and U.S. parent's ownership stake. The most extensive data are collected in benchmark years - 1982, 1989, 1994, 1999. BEA uses reported data to estimate universe totals when surveys cover only larger affiliates or when only certain affiliates provide information on particular survey forms. To avoid working with estimated data, only affiliates required to provide all the information associated with a particular analysis are considered in this paper. Additional information on the BEA data can be found in Mataloni (1995).

${ }_{22}$ Furthermore, in each manufacturing industry except food manufacturing, this kind of licensing accounts for between $80 \%$ and $99 \%$ of total royalty payments from affiliates to parents. Even in food manufacturing, technology licensing accounts for more than $50 \%$ of the total.
} 
supposed to apply a fair market price. Although governments are aware of these incentives and try to use their enforcement powers to ensure that royalties do not deviate from reasonable values, Hines (1995) and Grubert (1998) do find evidence of tax effects on reporting. Fortunately, these papers indicate that host country income tax rates and withholding tax rates can be used to control for the effects of tax incentives on reported intrafirm royalties. $^{23}$

BEA also collects data on royalty payments made by arm's length foreigners to U.S. firms on the Annual Survey of Royalties, License Fees, and Other Receipts and Payments for Intangible Rights Between U.S. and Unaffiliated Foreign Persons. A sample covering 1987 forward is drawn from the results of this survey. Since these payments are between unrelated parties, they are not subject to concerns about manipulation for tax purposes. A large fraction of firms that file responses in this survey are also multinational firms that respond to the Survey of U.S. Direct Investment Abroad, thus providing firm level coverage of technology transfers to both affiliated and unaffiliated parties in individual countries through time.

Table I displays descriptive statistics for the benchmark years in which BEA collected the most extensive data on U.S. foreign affiliates. The sample includes firms that were active in countries that undertook the IPR regime changes described below. In the most recent benchmark year, 1999, the sample includes more than 5,000 affiliates of more than 1,000 parent companies.

\footnotetext{
23 Even when multinationals do not deliberately misrepresent the value of technology transfers for taxrelated reasons, one still may doubt the extent to which the recorded licensing payments reflect the full economic value of technology provided by the parent to the affiliate. This is particularly true when there is no well-developed external market for the technology. However, parent reporting does not pose a problem for our econometric inference as long as recorded payments consistently misestimate the full value of technology transferred.
} 


\subsection{Data from Other Sources}

A number of other databases are used to augment the information on U.S. firms in the BEA data. In order to obtain information on parent firm R\&D expenditures in years in which this item was not captured in BEA surveys, the BEA data on publicly traded parents is linked to COMPUSTAT using employee identification numbers. Parent firm data is also linked to data on patenting activity captured in the NBER patent citation database. $^{24}$ This comprehensive database covers all patents granted by the U.S. Patent and Trademark Office (U.S. PTO) throughout the 1982-1999 sample period. These data provide a rich picture of the evolving technological trajectories of parent firms and are used to test if patent reforms have larger effects for firms that make more extensive use of the U.S. patent system prior to the reforms.

Data on patent filings in the countries that underwent patent reform provide additional information on the level of technology being transferred. Data on patent applications, broken down by nationality of applicant (foreign vs. domestic), are available from the World Intellectual Property Rights Organization (WIPO). If patents provide little or no protection in a country, there is little incentive to patent. If multinationals respond to an IPR reform that substantially strengthens patent rights by increasing the volume of technology being transferred (rather than merely increasing the price of technology that has already been introduced to the market in question), then this should be reflected in an increase in both the level and the growth rate of total patent

\footnotetext{
${ }^{24}$ This comprehensive data set on U.S. patents is documented in Hall et. al. (2001). Linking these data to BEA data requires the use of a mapping between the assignee codes used by the U.S. PTO to identify patent applicants and the CUSIP identifier codes used by the COMPUSTAT database created for all firms in the 1989 COMPUSTAT data.
} 
applications by foreign entities. The analysis examines trends in domestic and foreign patent applications over the 1982-1999 period. Descriptive statistics of patent application counts are provided in Table I, as are descriptive statistics for other variables that are used in the regression analysis that follows.

Finally, information on the timing and content of IPR regime changes come from a number of sources. Our starting point was the complete set of significant patent reforms identified by Maskus (2000). Information on the details of individual reforms was obtained from Ryan (1998), Uphoff (1990), and Sakakibara and Branstetter (2001), and various reports published by the patent agencies. We also undertook a series of interviews with multinational managers, legal experts on intellectual property rights based in some of the reforming countries, and international IPR consultants, in order to understand better the substance of the reforms and to confirm their timing. ${ }^{25}$ Table II displays the list of patent reforms considered in the analysis that follows, and Appendix A provides additional details about these reforms. This is not a complete or exhaustive list of IPR regime changes that occurred over our sample period. For instance, some countries undertook reforms of their copyright laws in ways that impacted the computer software and entertainment industries - these are not studied in the current paper. ${ }^{26}$

\section{Results}

\subsection{Technology Transfer to Affiliates}

To provide a general sense of trends in technology transfers, Figure 1 displays pre- and post reform averages of the ratio of aggregate royalties to aggregate sales in each

\footnotetext{
25 By prior agreement, our interviewees must remain anonymous.

26 An additional complication is that some countries undertook a series of patent reforms in different years. Our current analysis focuses on the particular change to the patent system judged most likely to impact technology licensing by foreign firms.
} 
country and year. Each of the unshaded bars illustrates the average pre-reform ratios, and the shaded bars illustrate similar averages for the post reform period. These are simple unconditional averages, but they are suggestive of an increase in the value of royalty payments relative to sales increases around the time of IPR reform. Furthermore, it is clear that affiliates in the high patent sample make more extensive use of intangibles provided by the parent and that the ratio of royalty payments to sales increases by the largest amount for this sub-sample when reforms occur. ${ }^{27}$

Of course, it is necessary to move beyond this figure to estimation of regressions that control for other factors influencing technology transfer and affiliate performance. Results of regression analysis of royalty payments made by affiliates located in the reforming countries to their parents based on specification (1) are reported in Table III. ${ }^{28}$ Columns (1)-(3) report the impact of IPR reform on log of the value of recorded licensing payments to the parent firm. ${ }^{29}$ The specification in the first column is run on the full sample of affiliates, and the positive and statistically significant coefficient on the post reform dummy indicates that intrafirm royalty payments increase at the time of reforms. As additional regressors, all specifications in the table include the difference between the corporate income tax in the host country and the U.S., the host country withholding tax

\footnotetext{
${ }^{27}$ Recall that the high patent sample includes affiliates of parents that, over the four years prior to a particular reform, average at least as many U.S. patent applications as the parent of the median affiliate in the reforming country over the same period.

${ }_{28}$ The sample used in generating Table III uses data on affiliates of U.S. firms in the reforming countries listed in Table II as well as data on their parent firms. That is, data are drawn from countries that undergo IPR reform at some point over the 1982-1999 period. An expansion of the sample to include affiliates based in all countries yielded results very similar to those shown in Table III. These results and others referred to in the text but not shown in the tables are available from the authors upon request.

29 A large number of affiliates, particularly those in low-tech industries, report zero values for technology transfer in most years. We thus added 1 to all observations and took the log of the resulting values. This transformation is standard in the older R\&D and productivity literature. Robustness checks described in the text remove affiliates that do not make royalty payments from the sample.
} 
rate, an indicator of host country FDI restrictions, measures of host country openness to trade, and the log of host country GDP per capita. ${ }^{30}$

The specifications in columns (2) and (3) examine how the effects of IPR reform differ for affiliates of parents that do and do not make extensive use of patents in the U.S. Since these specifications require information on the patent activity of parents, only affiliates of firms that can be linked to firms in the NBER patent database are included in the sample. The high patent use dummy is equal to one for affiliates of parents that, over the four years prior to a particular reform, average at least as many U.S. patent applications as the parent of the median affiliate in the reforming country over the same period. The coefficient on the post reform dummy in column (2) is positive but small and insignificant, while the coefficient on the post reform dummy interacted with the high patent use dummy is positive, large, and significant. These results imply that the increases in technology transfer as measured by royalty payments that occur around the time of IPR reform are concentrated among affiliates of parents that use patents extensively. These affiliates experience an increase in royalty payments of about $29 \%$. This is an annual increase in technology flows from parent to affiliate. Cumulated over several years, it implies a substantial increase in the technology intensity of the affiliates of patent-intensive parents.

Similar results are obtained from the specification presented in column (3) that also includes the $\log$ of affiliate sales, the $\log$ of parent $R \& D$ expenditures, and the log of parent system sales. The first of these is meant to control for the expanding demand for technology of an affiliate as it grows, while the latter variables control for the expanding

\footnotetext{
${ }^{30}$ Including measures of U.S. dollar real exchange rates vis-à-vis the host country currency did not qualitatively effect the results reported here.
} 
potential supply of technology of a parent as it invests in R\&D and grows in size. ${ }^{31}$ The interaction term of the reform dummy with the high patent use dummy remains positive and significant here.

The specifications presented in columns (4)-(6) of Table III control for the scale of affiliate activity more directly by scaling royalty payments by sales. The results of these specifications reveal whether affiliates use technology provided by the parent more intensively after reforms occur. The positive and significant coefficient on the post reform dummy in column (4) indicates that this is the case. The samples used in the last two specifications again include only affiliates of firms that can be linked to the NBER patent database. The coefficients on the post reform dummy interacted with the high patent use dummy are positive and significant in these specifications, indicating larger increases in the value of parent provided intangibles, relative to sales, for affiliates that have parents that make extensive use of the U.S. patent system.

To allow for a more direct comparison with the effects reported in columns (1)(3), it is helpful to calculate the elasticity of the royalty to sales ratio with respect to reform. To calculate this elasticity, we differentiate $\log (1+$ royalties/sales $)$ with respect to reform. Defining ratio = royalies/sales, this gives us:

$$
\frac{d \log (1+\text { ratio })}{\text { dreform }}=\frac{\left(\frac{\text { dratio }}{\text { dreform }}\right)}{1+\text { ratio }} \cong \frac{\left(\frac{\text { dratio }}{\text { dreform }}\right)}{\text { ratio }} * \text { ratio }=\varepsilon_{\text {ratio }} * \text { ratio }
$$

31 As already noted, we recognize the potential endogeneity of these variables in this context. However, the purpose here is not to derive structural estimates of, for instance, affiliate size on technology transfers. Rather, we only include these variables to control for parent-firm specific changes in technology supply and affiliate-specific changes in technology demand. 
Where $\varepsilon_{\text {ratio }}$ is the elasticity of the royalty to sales ratio with respect to reform. From Equation (1), we observe that $\varepsilon_{\text {ratio }}{ }^{*}$ ratio is given by the coefficient on our post-reform dummy, $\beta_{4}$, which takes on a value of 0.008 . Since the mean value of ratio is 0.077 , this implies that $\varepsilon_{\text {ratio }}$ is approximately ten percent. For the high patent subsample, the implied effect of reform, based on the last two specifications, is 0.017 , which implies an elasticity of 22 percent. These values are roughly comparable to those generated by the level regressions reported above.

We subjected these results to a number of robustness checks. We incorporated parent firm - year fixed effects into our regression. We dropped all affiliates that report zero licensing payments. We expanded the sample to incorporate affiliates in all countries - not just those that underwent reform during our sample period. To address the concern that our results might be driven by pharmaceutical firms, we dropped all affiliates in that industry and re-ran the specifications above. None of these alternative specifications qualitatively changed our results.

We also used propensity score techniques to match affiliates in the high patent sample in a country undergoing reform with another affiliate of the same patent-intensive parent firm located in a country that was not undergoing reform at that time. This allowed us to compute "difference-in-difference" estimates of the impact of IPR reform on licensing, akin to those that have become common in the labor literature. The results of this exercise also indicate an increase in licensing for this sub-sample that is similar to that shown in Table III.

Our estimation strategy treats the timing of IPR reform in a given country as exogenous, at least with respect to the activities of U.S.-based multinational firms and 
their affiliates. Several different hypotheses can motivate concern over the potential endogeneity of reforms. The most plausible of these hypotheses relates the development of a nation's IPR system to its overall level of economic development and technological maturity. According to this argument, at an early stage of development a strong patent system is neither essential nor necessary. In fact, to the extent that it slows the diffusion of technology through imitation, it may even be counterproductive. Once a nation reaches a certain threshold level of development, however, internal and external pressure builds for a stronger patent system. This raises concerns that the nations in our sample were all reaching this threshold at about the time their regimes changed. However, a casual look at the basic economic attributes of the IPR reforming countries in our sample drives home the point that they were at very different levels of economic development, and therefore could not have possibly been reaching a common development threshold at the time of their IPR reform. ${ }^{32}$

Another potential source of endogeneity is that reforms could have been driven by the desire of U.S. multinationals to obtain advantages in reforming markets. This argument is premised on the assumption that these firms developed a list of lucrative potential markets, and pushed the U.S. government to apply diplomatic pressure on selected countries, at precisely the time that they wished to increase technology transfers. A first response to this concern is to observe that the relative value of stronger IPR in these countries is almost certainly correlated with levels of economic development, but reforms occur in countries with heterogeneous wealth levels. In addition, it is useful to

\footnotetext{
${ }^{32}$ IPR reform took place in Japan when per capita GDP was at a level of nearly $\$ 30,000$ per year. In Korea and Taiwan, reform took place when per capital GDP was about $\$ 10,000$ per year. In Mexico and Thailand, reforms occurred when per capita GDP was about $\$ 5,000$ per year, and in China - at least on paper - a reform took place when per capita GDP was well below $\$ 1,000$ per year.
} 
review the well documented diplomatic history of many of the regime changes. Ryan (1996), Uphoff (1990), and our interviews with multinational managers and resident legal experts indicate that US pressure interacted in complicated ways with domestic counter pressure, and this interaction introduced an element of randomness into the timing of reforms that is exogenous to the wishes of U.S. multinationals. ${ }^{33}$

Despite these arguments, it is important to acknowledge that IPR reform is not a randomly assigned treatment. It is not possible to know what would have happened in the counterfactual world in which IPR reforms did not occur, and this is an important caveat in using our results to predict the impact of IPR reforms in countries outside the of sample. $^{34}$

\subsection{Affiliate $R \& D$ Spending}

The pattern of increased royalty payments after reform is consistent with parents supplying more technology to their affiliates after reform, but this pattern could also be consistent with parents charging higher prices for the same level of technology provision. As discussed in Section 2, affiliate R\&D is often focused on modification of the parent firm's technology to meet local market conditions. Therefore, affiliate R\&D is a complement to technology imports from the parent. If IPR reform stimulates an increase

\footnotetext{
${ }^{33}$ Further evidence of this lack of diplomatic omnipotence is provided by the timing of other reforms that MNCs would obviously have an interest in promoting - such as a lifting of FDI restrictions and an expansion of openness to trade. These controls have little impact on the results of this paper because they were not coincident with IPR reform. For example, South Korea reformed its patent system in the late 1980s, but U.S. multinational's ability to profit from this was limited by the fact that South Korea maintained limits on FDI until the Asian Financial Crisis of 1997-98. On the other hand, US MNCs had a substantial FDI presence in countries like the Philippines and Brazil, but these countries could not be induced to change their IPR regimes until 1997 - and these changes were mostly in response to the requirements of TRIPs rather than a response to diplomatic pressure from the U.S.

${ }^{34}$ This problem is common to much of the recent work on such topics as the impact of customs unions on trade flows, the impact of common currencies on investment flows, and the impact of bilateral tax treaties on FDI.
} 
in the volume of technology deployed, then it should also stimulate an increase in affiliate $R \& D$ spending.

To test if changes in $R \& D$ activity indicate any increase in the volume of technology transferred, the analysis in Table IV examines the impact of IPR reform on affiliate R\&D activity. The specifications presented parallel those presented in Table III, with the only difference being that the $\log$ of affiliate $R \& D$ expenditures and the $\log$ of affiliate $R \& D$ expenditures scaled by sales are used as dependent variables. ${ }^{35}$ The results presented in column (1) imply positive, marginally significant effect of IPR reform on the $R \& D$ spending of the average affiliate in the full sample.

The specifications in column (2) and (3) include the post reform dummy interacted with the high patent use dummy to test if the effects of IPR reform are particularly concentrated among firms that make the most extensive use of patents in the U.S. The large positive and significant coefficients on the interaction terms illustrate that this is the case. The results in column (3), for instance, imply that IPR reform leads to a $27 \%$ increase in $\mathrm{R} \& \mathrm{D}$ spending by the affiliates of patent-intensive parents. Because $\mathrm{R} \& \mathrm{D}$ represents a cost born by the parent system, the coincidence of the measured increase in $R \& D$ spending with the measured increase in licensing payments suggests that at least some component of the latter represents a real increase in the deployment of technology to affiliates.

Columns (4)-(6) of Table IV provide the results of specifications in which R\&D expenditure is scaled by affiliate sales. Although the results in column (1) indicates that

\footnotetext{
${ }^{35}$ A large number of affiliates, particularly those in low-tech industries, report zero values for R\&D expenditures in most years. We thus add 1 to all observations and took the $\log$ of the resulting values. This transformation is standard in the older R\&D and productivity literature. Robustness checks described in the text remove affiliates that do not conduct R\&D from the sample.
} 
there is a small, marginally significant decline in R\&D intensiveness among the full sample of affiliates at the time of reforms, the specifications in column (5) and (6) reveal a distinct effect for the high patent sub-sample. Affiliates of parents that make extensive use of patents in the U.S. increase their R\&D intensiveness by more than other affiliates when IPR reforms occur.

The robustness of our results on affiliate $R \& D$ spending was tested in a number of alternative specifications. We incorporated parent firm - year fixed effects into our specification. We dropped observations for affiliates that report zero R\&D spending. We expanded the sample to include all available countries, not just those undergoing IPR reform over our sample period. As with our results on royalty payments, we also used propensity score techniques to match affiliates in the high patent sample in countries undergoing IPR reform to an affiliate of the same patent-intensive parent located in a country that was not undergoing IPR reform at that time. The resulting "difference-indifferences" estimate of the increase in annual R\&D spending was qualitatively similar to that reported in Table IV.

\subsection{Arm's length licensing}

U.S. firms not only receive royalty payments for the sale or use of intangibles from their affiliates but also from unaffiliated foreigners. Table V displays results of tests of how these royalty payments respond to changes in IPR regimes. The first two columns examine flows to firms that do and do not have affiliates in the country from which payments are made. The coefficient on the post reform dummy is positive and marginally significant in column (1). The next column considers flows from unaffiliated 
parties in a particular country to parent firms that have an affiliate in that country. There is no evidence that IPR reform affects these flows. ${ }^{36}$ The final column presents a specification that analyzes flows from countries to firms that do not have affiliates in those countries. The results in column (3) indicate that IPR reforms have a measurable impact for firms that do not have affiliates in reforming countries prior to reforms.

These findings are consistent with the predictions of the model laid out in Appendix B, provided it is less expensive to transfer technology within firms rather than across firm boundaries. To the extent to that indigenous enterprises lack either the technical skill or access to the capital necessary to fully exploit U.S. multinational parent firm technology, it may be optimal to deploy technology through foreign affiliates. ${ }^{37}$ The inability of foreign legal regimes to perfectly enforce complicated contracts may influence the shape of the expropriation function in a way that favors deployment within affiliates. Finally, it has been well documented in other recent research that U.S. multinationals have been increasingly outsourcing non-strategic activities, but increasingly "in-sourcing" strategically sensitive activity in recent years. ${ }^{38}$ This is consistent with the general pattern of the reported results.

\subsection{Resident versus Non-Resident Patenting}

Figure 2 presents a first look at how patent filings by foreigners and domestic residents change after IPR reform. This figure presents ratios of patent filings in the

\footnotetext{
36 The evident preference for U.S. multinationals to transfer new technology to wholly owned subsidiaries is documented elsewhere. See, for instance, Lee and Mansfield (1996).

37 Considerable support for this view is provided by Lee and Mansfield (1996). These authors take a cross-sectional approach, but they also find that activity within wholly owned subsidiaries is more responsive to changes in IPR regimes than activity within entities over which the multinational parents have less control.

38 See, for instance, the work of Desai, Foley, and Hines (2004).
} 
years around the time of reform to the level recorded in the year immediately preceding patent reform. This figure suggests that, relative to the pre-reform period, patenting grows for nonresidents after reform. However, patenting by domestic residents is flat. This pattern is broadly consistent with the findings of Lerner $(2001,2002)$. It also suggests that at least one component of the observed increase in licensing payments is connected to an increase in the volume of technology transferred.

To study patterns in patent data more carefully, the analysis presented in Table VI measures the impact of IPR reform on patent filings by both domestic and foreign innovators. The log of the counts of patent filings is regressed on the post reform dummy, an interaction term between the post reform dummy and an overall time trend, country and year fixed effects, country specific time trends, and some additional controls. Columns (1)-(4) present specifications where the dependent variable is the log of resident patent filings. In column (1), the coefficient on the post reform dummy is indistinguishable from zero, indicating that resident patent filings do not increase after reforms occur. Column (2) includes two additional controls: the log of host country GDP per capita and the log of host country net inward FDI. The post reform dummy remains insignificant. As the results in the next two columns show, the post reform dummy interacted with a time trend is also insignificant, indicating that the growth rate of resident patent filings does not increase after reforms. These findings are consistent with Lerner (2002).

Columns (5)-(8) present similar specifications for non-resident patent filings. There is robust evidence that these filings experience large increases and that these filings grow at an increased rate after reforms. The coefficient on the post reform dummy in 
columns (5) and (6) imply increases in non-resident filings that exceed 35\%. The positive and statistically significant coefficients on the post reform dummy interacted with the time trend in columns (7) and (8) imply faster growth over time in the number of non-resident filings after reforms. These findings provide additional evidence that MNEs increase the quantity of technology transferred after IPR reform.

\section{Conclusion}

Understanding the effects of intellectual property rights on various types of international activity is an important agenda in economic research. This paper empirically tests the hypothesis that IPR reforms increase technology transfers between countries by analyzing how measures of U.S. affiliate activity and levels of foreign patenting change in a set of 12 countries that undergo reforms.

There are some significant advantages associated with this approach. By examining discrete reforms of IPR, the analysis includes country or affiliate fixed effects and therefore controls for time-invariant country and firm characteristics that are often correlated with factors that influence the decision to transfer technology. The firm-level data used in this paper cover affiliates of U.S. MNEs that report information in a consistent way across countries. The use of these firm-level data also permit tests that reveal whether IPR reforms have the largest consequences for firms that would be expected to value such reforms the most.

The results provide strong evidence that U.S. multinationals respond to changes in IPR regimes abroad by increasing technology transfers to reforming countries. In the wake of legal reforms that strengthen patent rights, intrafirm royalty payments made by 
affiliates to parents increase, and these increases are concentrated among affiliates of parents that intensively patent innovations in the U.S. prior to reforms. Analyzing patterns in affiliate $R \& D$ spending, which is a complement to the transfer of technology, indicates that at least some component of increased royalty payments reflects increases in the volume of technology transferred and not merely increases in the price of technology transferred. Affiliates increase their R\&D expenditures at the time of reforms. These increases are also concentrated among affiliates of parents that use U.S. patents intensively, and they are of a similar magnitude to the changes in royalty payments. Additional evidence that the volume of technology transferred increases comes from patent data drawn from countries that undergo reforms. While the level of domestic patent applications is unaffected by reforms, foreign patent applications increase, in terms of both levels and growth rates.

These results are not, of course, sufficient to demonstrate that IPR reform is welfare enhancing for the reforming countries. The analysis does not consider the impact of reforms on locally owned firms that may be displaced after reforms nor does it examine the effects of the reforms on the pace of innovation in non-reforming countries. However, given the lack of evidence that IPR reform spurs domestic innovation, increases in technology transfer are likely to be a necessary condition for IPR reform to increase welfare in reforming countries. Our results suggest that this condition is met.

The findings in this paper could be extended in several ways. One promising direction would be to use patent data broken down by narrowly defined technology class and the nationality of the inventor. In the absence of strong IPR protection, multinationals may limit the deployment of certain critical technologies - typically, more 
advanced technologies -- for fear that they will be imitated by local rivals. The existence of stronger IPR could induce multinationals to deploy these technologies because they now have a legal remedy against imitation. Using highly disaggregated data on international patenting available from the European Patent Office, we can actually track the filing of patent applications in sensitive, highly advanced technological areas. While data on royalty payments provide us, at least in principle, with measures of the economic value of technology deployed by affiliates, highly disaggregated patent data allow us, in principle, to track the technological content of the underlying technology flows.

The international economics literature has established that changes in the IPR environment will affect the trade-off between licensing, local production, and exports. It is possible to embed IPR regime changes within a larger model in which the level of investment in a country and exports from production facilities located outside the country are also endogenously determined. The imposition of more structure holds the promise of providing further insight on the global welfare impact of recent changes in IPR systems. Recent contributions to the theory of the multinational firm provide us with a useful foundation on which to build. ${ }^{39}$

39 See Markusen (2000) and, for a treatment that combines empirics and theory, Carr, Markusen, and Maskus (2001). 


\section{Appendix A: Details of Reforms}

Since the intent of this paper is to draw general lessons from the last twenty years of IPR reform, we do not analyze particular aspects of individual IPR reforms in detail. However, this appendix provides a brief description of the various IPR reforms studied in this paper. More details are available from the authors upon request.

As a prelude to this description, it is important to emphasize two points. First, in most countries, reform of the IPR system is an ongoing process. The dates assigned to each country mark a particularly significant stage in this process - a widely recognized turning point in the evolution of the system. Nevertheless, it should be emphasized that this date marks the onset of a process rather then the establishment of a henceforth unchanging IPR regime. Since identification in the empirical analysis comes from differences in the timing of reforms, the analysis is testing if multinational technology transfer changes when these turning points occur.

Second, we consulted wide range of sources concerning the reform process in the sample countries. While our starting point was the general description of international IPR reforms found in Maskus (2000), that information has been heavily supplemented by a close reading of other secondary sources, extensive interviews with patent lawyers based in the reforming countries, multinational managers with extensive experience in IPR-intensive industries in the reforming countries, and consultants specializing in international IPR issues. There is generally a broad consensus concerning the date of the significant turning point in IPR reform in each country. 
The IPR reforms in the sample can be grouped into four overlapping categories: reforms that changed the administration of the patent law and related statutes, reforms that changed both the law itself and the administration of the law, reforms that included the expansion of patentable subject matter, and reforms that involved the promulgation of a new law, but little in the way of de facto administrative change.

An example of a reform that might be primarily classified in the first category is the Japanese patent reform of 1995. This reform followed changes to Japan's patent law in the late 1980s, ratification of the TRIPs agreement, and the successful conclusion of negotiations with the United States to harmonize the two countries' patent systems. ${ }^{40} \mathrm{~A}$ key feature of this reform package was the replacement of Japan's pre-grant opposition system with a post-grant opposition system. Under the prior regime in Japan, patent applications were laid open to public inspection prior to the grant. Interested parties could then contest the patent grant through a quasi-judicial procedure administered by the Japanese patent office. This pre-grant opposition system led to long, unpredictable delays in the granting process and considerable ex ante uncertainty concerning the degree to which the patent office would uphold the claims in a patent application. The postgrant opposition system allowed for more or less automatic granting of a patent once patent examiners had studied the patent application's claims and certified their validity. This administrative reform also coincided with a substantial increase in the number of patent examiners and a further computerization of the Japanese patent office (JPO), both

\footnotetext{
40 Ratification of the TRIPs agreement necessitated an extension of patent length in Japan (from fifteen to twenty years) and other, mostly technical changes in the patent statute. The 1995 reforms helped cement a process of strengthening of the Japanese patent system that began in the late 1980s (Sakakibara and Branstetter, 2001). For a careful historical perspective on Japanese patent reform that brings one up to the developments of the late 1990s, see Goto (2003).
} 
of which strengthened the administrative capacity of the JPO and reduced delays in examination and the granting of patents.

Perhaps the best example of a reform that changed both the substance of the law and its administration is the reform that took place in Mexico in $1991 .^{41}$ The preceding IPR legal regime was effectively abolished and a completely new legal system with a new administering institution was established. Whereas the implicit goal of the previous IPR regime had been to limit the ability of patent holders to control access to their patented technology, the goal of the new regime was explicitly to ensure adequate protection to incumbent patent holders. Patent protection was expanded to incorporate pharmaceutical and chemical products. Previous restrictions on terms of licensing technology were abolished, allowing these terms to be determined at the discretion of the contracting parties. Legal tools were introduced to aid in the prosecution of patent infringement, including inspections of the facilities of potential infringers, the seizure of goods and closure of facilities involved in infringement, and the effective prohibition of parallel imports.

The Brazilian patent reform of 1997 was of a similar nature. In addition to significant legal changes, the reform also introduced guidelines for judges to use in the determination of damages as a result of infringement. Judges were also provided with additional means to stop illicit activities including powers to grant preliminary injunctions to seize infringing products and close down infringing production. ${ }^{42}$ Spain's

\footnotetext{
41 While such surveys also have their problems, it is worth pointing out that surveys of multinational managers (such as the World Competitiveness Report, issued by the World Economic Forum) tend to give high marks to the effective enforcement of the new IPR regime in Mexico.

42 From the perspective of multinational pharmaceutical companies, the Brazilian reform process took a step backward in 2000, when the Health Ministry took steps to block the granting of new pharmaceutical products. According to our sources, these difficulties persist to the present.
} 
integration with the EU also required fundamental changes in both Spanish patent law and practice in 1986, although the implementation of key changes in Spanish law were delayed until 1992. At least on paper, reforms in Turkey and in the Philippines also had some of these characteristics in that the institutions administering the patent system were changed at the same time as the law itself. While perceptions differ among multinational managers, our interviews conveyed the impression that enforcement has been more problematic in these contexts than in Mexico or Spain. Turkish patent law was changed in the mid-1990s, but implementation of key features of the law was explicitly delayed until 2005. Implementation was later moved up to 1999, but this feature clearly muted the initial reaction of multinational firms.

A number of patent reforms in our sample broadened the definition of patentable subject matter to include pharmaceutical, food, and agro-chemical products. Reforms with this feature included those of Spain (1986), South Korea (1987), Mexico (1991), Brazil (1997), and Turkey (1995). Prior to this expansion, foreign and domestic inventors could generally patent the process by which a chemical or pharmaceutical compound was produced, but not the compound itself. Because of the ease with which many such products could be produced through alternate means, the restriction to process patents drastically limited the degree of IPR protection in these fields. The extension of patents to these areas was quite a significant change, and one would expect the growth of foreign patenting after reform to be disproportionately concentrated in these fields. In fact, some countries, including Mexico and Brazil, actually introduced a provision whereby patents for which the international 12 month "grace period" had already expired 
could be granted in these formerly restricted areas. ${ }^{43}$ The effectiveness with which these provisions have been enforced can sometimes be inferred from local financial markets. For instance, an event study of stock prices of South Korean pharmaceutical firms (most of which focused on copycat production of drugs for which patents were not allowed in Korea) shows that these prices plummeted with the implementation of the 1987 reforms. $^{44}$

Finally, there are reforms for which effective implementation has been almost completely absent. In 1993, after extensive negotiations with the United States, China introduced a patent statute which seemed to offer substantial protection for patent holders. However, this law has not been effectively enforced. ${ }^{45}$ Interestingly, our $^{2}$ regression results tend to confirm the conventional wisdom regarding the IPR environment in China. When versions of equation (1) are estimated using only Chinese data, there is no measurable response whatsoever to the enactment of Chinese patent reform - precisely the result one would expect if effective enforcement were absent and widely recognized as such. On the other hand, estimates of equation (1) on data for countries such as Mexico, where the reforms are widely considered to have been both substantial and effectively enforced, tend to give large and statistically significant results.

43 International patent conventions prior to the TRIPs Agreement allowed an inventor up to 12 months to choose the countries in which she would seek patent protection and initiate the patent application process. This period typically dated from the application for patent protection in the first country chosen by the inventor. After this 12 month period expired, the invention would be effectively regarded as part of the "public domain" in all countries in which the inventor had not explicitly sought protection. Recall that there is no global patent system. Patent protection must be sought in each country.

44 See La Croix and Kawaura (1996).

45 Argentina's 1996 pledge to strengthen the IPR environment, particularly for pharmaceutical products, has also been heavily criticized due to weak enforcement. 


\section{Appendix B A Simple Model of IPR and Firm-Level Technology Transfers}

We provide here a simple firm-level model of responses to IPR regime changes. Since we are generally considering reactions to discrete IPR regime shifts in individual markets that may not loom large in a firm's overall level of sales, we may safely take the firm's stock of innovations as being held constant, and may therefore ignore (at least for now) the induced effect of IPR reform on future innovation.

Our model is similar to that of Green and Scotchmer (1995), in that we consider the sequential choice of introduction of technology to a new market followed by a decision of whether to license to other producers. However, in transforming their model to the context of technology transfers, we make a number of changes, including the incorporation of a second-stage model of spatial competition.

We model a multinational firm that is considering a transfer of technology that will generate additional profits. The cost of transferring this technology is given by $t$. We may think of this as an innovation that improves an existing good, or an entirely new product, and normalize the 'no transfer' case to yielding a zero payoff for the multinational. Below, we will allow this transfer cost to depend on whether the technology is being licensed $\left(t_{l}\right)$ or used by a multinational affiliate $\left(t_{a}\right)$. This differential may arise, for example, because of the greater difficulties in transacting across firm boundaries.

Conditional on deciding to enter the market, the firm must decide whether to transfer the technology through a local affiliate or by licensing the technology to an unrelated party. If the technology is licensed to an outside party, a licensing fee, $L$, is 
paid by the licensee. ${ }^{46}$ If the firm chooses to produce through a local affiliate, then it competes directly in the market. ${ }^{47}$ If entry occurs through licensing, there is some probability that the licensee fails to pay the licensing fee $(q)$, and this depends on the extent of IPR enforcement, $s$, so that $q=q(s)$.

The structure of competition, conditional on entry, also depends on the extent of IPR protection. We model this as a simple "linear city" model of product differentiation on the interval $[0,1]$, with a uniform distribution of customers who face transport costs $m x$, where $x$ is the "distance" from the firm that makes the sale (see, for example, Tirole, 1993, for details). ${ }^{48}$ The multinational occupies the point at zero, and we assume that the closest competitor is given by $s$, so that improved IPR broadens the firm's monopoly power. On [s,1], we assume free entry, so that the price charged by this 'fringe' group will be unaffected by $s$ (let this price be $p_{o}$ ). For the multinational affiliate, the marginal cost of production is $c_{a}$, a constant. If entry takes place through exclusive arm's-length licensing, we assume that the licensee faces an exactly parallel set of circumstances, except possibly with a different marginal cost of production $\left(c_{l}\right)$.

The timing of the game is therefore as follows:

1. Decide whether to provide the technology to the market.

2. Choose mode of transfer (arm's-length licensing versus affiliate).

3. If entry through arm's-length licensing, technology is stolen with probability $q(s)$

4. Licensee/Affiliate competes in spatial differentiation game.

\footnotetext{
${ }^{46}$ We assume a lump sum licensing fee (independent of sales). This is optimal in the context of the simple model described here, since it avoids problems of double marginalization.

${ }^{47}$ For simplicity, we do not consider the case where profit may be maximized by entering through an affiliate and licensing. For this to make sense, it would have to be necessary for the multinational to either control downstream prices, or for a duopoly to generate greater profits that a monopoly. Furthermore, empirically, we largely see firms either licensing or transferring technology to affiliates, but not both. ${ }^{48}$ In this context, it is natural to think of distance as representing the gap between the characteristics of goods and the consumer's desires rather than geographical distance.
} 
To determine the equilibrium entry decisions of the multinationals, as a function of the model's parameters, we work backwards. In the final stage, the position of the marginal consumer, $x$, is determined by:

(1) $\left.\quad p_{a}+m x=p_{o}+m(s-x)\right)$

Hence,

(2) $\quad x=\frac{p_{o}+s m-p_{a}}{2 m}$

It is then straightforward to calculate the profit maximizing levels of output, price, and profitability as a function of the model's parameters, in particular, $s$. Profits are given by:

(3) $\quad \pi=\frac{p_{o}+s m-p_{a}}{2 m}\left(p_{a}-c\right)$

First order conditions therefore yield:

$$
\begin{aligned}
p_{a} & =\frac{1}{2}\left(p_{o}+s m+c\right) \\
q_{a} & =\frac{1}{4 m}\left(p_{o}+s m-2 c\right)
\end{aligned}
$$

Under these conditions, it is straightforward that:

(5) $\frac{d p_{a}}{d s}, \frac{d q_{a}}{d s}, \frac{d \pi}{d s} \geq 0$

The intuition is clear: greater IPR expands the product space over which the firm enjoys monopoly power. As a result, profits and price increase. While the firm's sales also increase, aggregate sales remain unchanged, by construction.

Note that the above description assumes that the multinational's monopoly price is low enough such that all customers are served. However, if we consider the possibility that consumers have a reservation utility, $u^{*}$, then a purchase will only be made if $u^{*}>p_{a}$ $+m x$. If price were already high enough that some customers were not served by any 
firm, then the extent of IPR would be irrelevant for the firm's pricing decisions, as it would already effectively have an effective monopoly over the relevant range. In this case, increasing IPR does not affect the multinational, but decreases the overall level of output, due to the further crowding out of the competitive fringe.

\section{Entry through arm's-length licensing versus affiliate}

We model the licensing to an unrelated party transaction as essentially the sale of the right to the product space, $[0, \mathrm{~s}]$, that the multinational enjoys in the previously described model of spatial competition. If this is the case, then the profit earned by the licensee may be calculated in exactly the same manner as above, with the total level of profits dependent upon $s$, as well as the firm's marginal cost of production. Once we add in the cost of transferring technology, which we expect to differ between arm's length and internal transfers, and the probability of no-license payment, we generate two obvious conditions on the subsidiary versus licensing choice:

(6) $(1-q(s)) L-t_{l}>\pi\left(s, c_{a}\right)-t_{a}$

( 7) $\pi\left(s, c_{l}\right)-q(s) L>0$

Equation (7) reflects the domestic firm's participation constraint, while (6) represents the multinational's trade-off between licensing and direct investment. Once again, it is straightforward that the choice is dependent on the level of $s$, and in particular, how this affects the probability of expropriation, $q(s)$, as $s$ increases. Furthermore, to the extent that domestic or foreign firms are more effective in serving a particular market, this will manifest itself in the form of differential values of $c_{L}$ versus $c_{f}$. Overall, it will not be 
possible to sign the licensing-affiliate choice as a function of $s$, as this will depend on transfer and production costs, as well as the shape of $q(s)$.

Working back to the final stage, it is again straightforward that, since both $\pi_{l}$ and $\pi_{a}$ will increase with $s$, technology transfers will increase with stronger property rights enforcement; as a result, profits are pushed toward the threshold at which they offset transfer costs.

We may now summarize the characteristics of our model that will be relevant for the empirical estimation:

1. An increase in IPR leads to an increase in technology transfers by multinationals

2. The extent to which these transfers take place through licensing to third parties relative to affiliates will depend on the relative expertise of the multinational relative to domestic producers $\left(c_{a}\right.$ versus $\left.c_{l}\right)$, the relative costs of transferring technology $\left(t_{a}\right.$ versus $\left.t_{l}\right)$, and the shape of the 'expropriation function', $q(s)$.

3. IPR improvements will increase firm profitability, output, and price. 


\section{References Cited}

Bartlett, C. and S. Ghoshal, 1990. Managing Innovation in the Transnational Corporation. In C. Bartlett, Y. Doz, and G. Hedlund, Eds., Managing the Global Firm. Routledge: London.

Bessen, J. and E. Maskin, 2000. Sequential Innovation, Patents, and Imitation. MIT Department of Economics Working Paper No. 00-01.

Branstetter, L., 2000. Is Foreign Direct Investment a Channel of Knowledge Spillovers? Evidence from Japan's FDI in the United States. NBER working paper no. 8015.

Brune, N., G. Garrett, A. Guisinger, and J. Sorens, 2001. The Political Economy of Capital Account Liberalization. Working Paper, Yale University.

Carr, D., J. Markusen, and K. Maskus, 2000. Estimating the Knowledge Capital Model of the Multinational Enterprise. American Economic Review 91: 693-708.

Clark, K. and T. Fujimoto, 1991. Product Development Performance: Strategy, Management, and Organization in the World Auto Industries. Harvard Business School Press, Boston, MA.

Cockburn, I. and J. Lanjouw, 2001. New Pills for Poor People? Empirical Evidence After GATT, World Development 29: 265-89.

Desai, M., C. Foley, and J. Hines Jr., 2004. The Costs of Shared Ownership: Evidence from International Joint Ventures. Journal of Financial Economics, forthcoming.

Eaton, J. and S. Kortum, 1996. Trade in Ideas: Patenting and Productivity in the OECD. Journal of International Economics 40: 251-278.

Fors, G., 1997. Utilization of R\&D Results in the Home and Foreign Plants of Multinationals. Journal of Industrial Economics 45: 341-358.

Glass, A. and K. Saggi, 2002. Intellectual Property Rights and Foreign Direct Investment. Journal of International Economics 56: 387-410.

Goto, A., 2003. Kyoshinka no Process toshite no Nihon no Tokkyo Seido to Gijutsu Kakushin (The Co-evolution of Japan's Patent System and Technological Progress). In A. Goto and S. Nagaoka, eds., The Intellectual Property System and Innovation (in Japanese). University of Tokyo Press: Tokyo.

Green, J. and S. Scotchmer, 1995. On the Division of Profit in Sequential Innovation. The Rand Journal of Economics 26: 20-33. 
Grossman, G. and E. L. C. Lai, 2002. International Protection of Intellectual Property. NBER Working Paper 8704.

Grubert, H., 1998. Taxes and the Division of Foreign Operating Income among Royalties, Interest, Dividends, and Retained Earnings. Journal of Public Economics 68: 269-290.

Hakanson, Lars, 1990. International Decentralization of R\&D - the Organizational Challenges. In. C. Bartlett, Y. Doz, and G. Hedlund, Eds., Managing the Global Firm. Routledge: London.

Hall, B., A. Jaffe, and M. Trajtenberg, 2001. The NBER Patent Citation Data File: Lessons, Insights, and Methodological Tools. NBER Working Paper 8498.

Hayes, R. and S. Wheelwright, 1988. Dynamic Manufacturing: Creating the Learning Organization. The Free Press: New York, NY.

Helpman, E., 1993. Innovation, Imitation, and Intellectual Property Rights, Econometrica 61: 1247-1280.

Heston, A., R. Summers, and B. Aten, 2002. Penn World Table Version 6.1. Center for International Comparisons at the University of Pennsylvania (CICUP).

Hines, J., 1995. Taxes, Technology Transfer, and R\&D by Multinational Firms. In M. Feldstein, J. Hines, and R. G. Hubbard, eds., Taxing Multinational Corporations. University of Chicago Press.

Keller, W., 2002. Geographic Localization of International Technology Diffusion. American Economic Review 92: 120-142.

Kuemmerle, W., 1999. The Drivers of Foreign Direct Investment into Research and Development: An Empirical Investigation. Journal of International Business Studies, 30 (1), pp. 1-24.

Lai, E. 1998. International Intellectual Property Rights Protection and the Rate of Product Innovation. Journal of Development Economics 55: pp. 133-153.

Lanjouw, J., 1997. The Introduction of Pharmaceutical Product Patents in India: "Heartless Exploitation of the Poor and Suffering?" NBER Working Paper 6366.

Lee, J. Y. and E. Mansfield, 1996. Intellectual Property Protection and U.S. Foreign Direct Investment. The Review of Economics and Statistics 78: 181-186.

Lerner, J., 2001. 150 Years of Patent Protection. NBER Working Paper No. 7478.

Lerner, J., 2002. Patent Protection and Innovation over 150 Years. NBER Working 
Paper No. 8977.

La Croix, S. and A. Kawaura, 1996. Product Patent Reform and Its Impact on Korea's Pharmaceutical Industry. International Economic Journal 10: 109-124.

Mansfield, E., D. Teece, and A. Romeo, 1979. Overseas Research and Development by US-Based Firms. Economica, 46: 187-96.

Markusen, J., 2000. Contracts, Intellectual Property Rights, and Multinational Investment in Developing Countries. Journal of International Economics, forthcoming.

Maskus, K., 1998. The International Regulation of Intellectual Property. Weltwirtschaftliches Archiv 134: 186-208.

Maskus, K., 2000. Intellectual Property Rights in the Global Economy. Institute for International Economics: Washington, D.C.

Maskus, K. and D. Eby-Konan, 1994. Trade-Related Intellectual Property Rights: Issues and Exploratory Results, in Analytical and Negotiating Issues in the Global Trading System, ed. by Alan Deardorff and Robert M. Stern. University of Michigan Press: Ann Arbor, MI.

Maskus, K. and M. Penubarti, 1995. How Trade-Related Are Intellectual Property Rights? Journal of International Economics 39: 227-48.

Mataloni, R., 1995. A Guide to BEA Statistics on U.S. Multinational Companies. Survey of Current Business 75: 38-53.

McCalman, P., 2001. Reaping What you Sow: An Empirical Analysis of International Patent Harmonization. Journal of International Economics 55: 161-186.

Nonaka, I. and H. Takeuchi, 1995. The Knowledge-Creating Company: How Japanese Companies Create the Dynamics of Innovation. Oxford University Press: New York, NY.

Ryan, M., 1998. Knowledge Diplomacy: Global Competition and the Politics of Intellectual Property. Brookings Institution Press: Washington, DC.

Sakakibara, M. and L. Branstetter, 2001. Do Stronger Patents Induce More Innovation? Evidence from the 1988 Japanese Patent Reforms. Rand Journal of Economics 32: 771-100.

Scherer, F. M. and S. Weisburst, 1995. Economics Effects of Strengthening Pharmaceutical Patent Protection in Italy. International Review of Industrial Property and Copyright Law 26: 1009-24. 
Smarzynska, B. 2000. Composition of Foreign Direct Investment and Protection of Intellectual Property Rights: Evidence from Transition Economies. Working Paper, World Bank.

Smith, P., 1999. Are Weak Patent Rights a Barrier to U.S. Exports? Journal of International Economics 48: 151-77.

Smith, P., 2001. How do Foreign Patent Rights Affect U.S. Exports, Affiliate Sales, and Licenses? Journal of International Economics 55: 411-439.

Tirole, J., 1993. The Theory of Industrial Organization. MIT Press, Cambridge, MA.

Uphoff, E., 1990. Intellectual Property and U.S. Relations with Indonesia, Malaysia, Singapore, and Thailand. Cornell Southeast Asia Program: Ithaca, NY.

Vernon, R., 1966. International Investment and International Trade in the Product Cycle. Quarterly Journal of Economics, 80: 190-207.

von Hippel, E., 1988. The Sources of Innovation. Oxford University Press, New York, NY.

Yang, G. and K. Maskus, 2000. Intellectual Property Rights and Licensing: An Econometric Investigation. Working paper, UC-Boulder. 
Figure 1: Aggregate royalty payments/aggregate sales. The clear bars indicate the average annual aggregate royalty payment to sales ratio for various samples of affiliates in reforming countries before reforms occur. Averages are calculated as the mean of annual ratios in each country over all years in the pre-reform period. The shaded bars depict average ratios for the year of and years following reform. The first two bars are for the full sample, the next two for affiliates of parents that cannot be matched to the NBER patent database, the third pair of bars are for the sample of affiliates of parents that do not make extensive use of patents in the U.S., and the final pair are for affiliates in the high patent use sample.

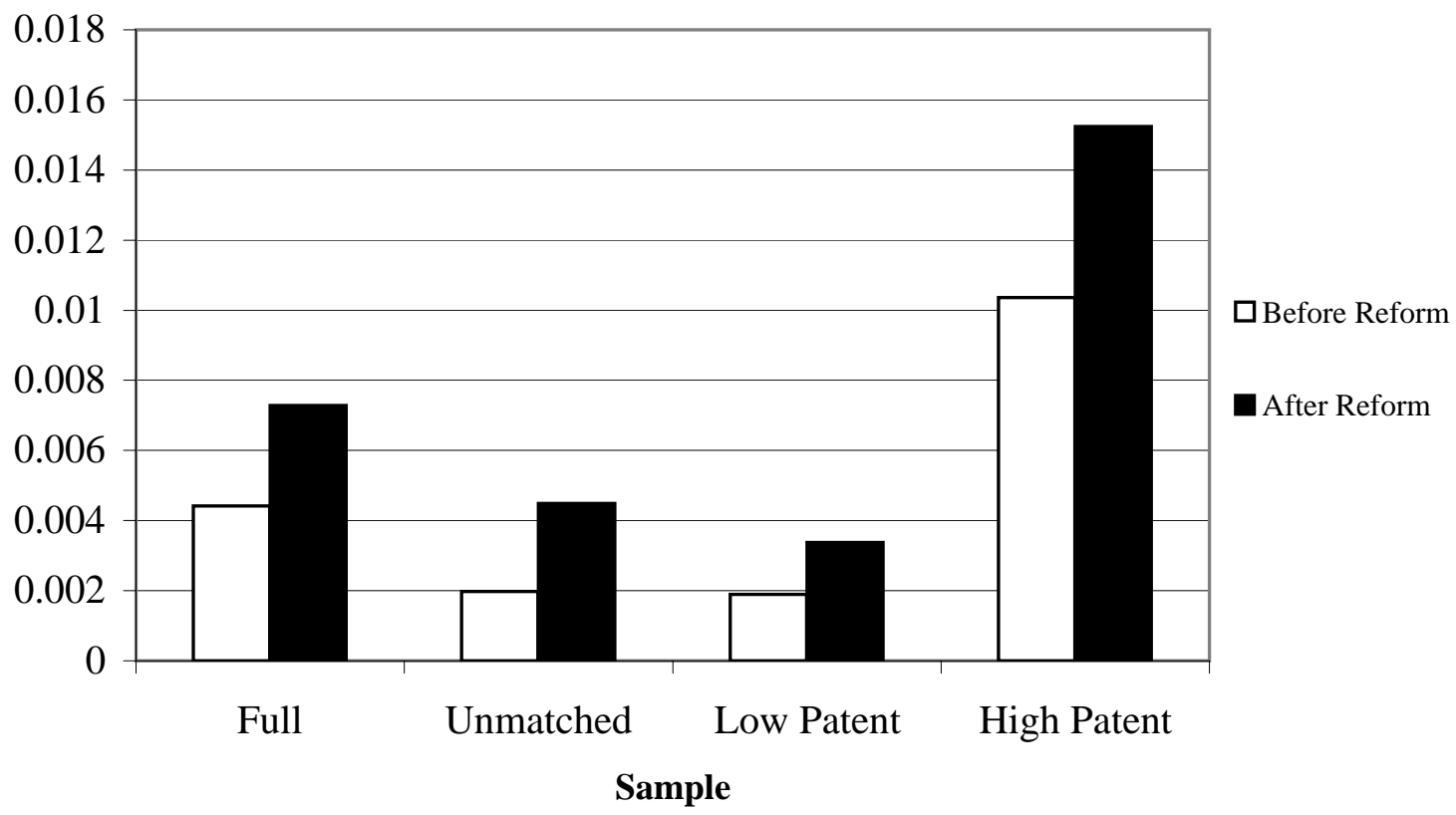

Figure 2: Resident and non-resident patent filings around the time of reforms The Non-Resident Patent Filings line traces out an index of foreign patenting around the time of reforms. This index is calculated by first computing the median ratio of the number of patent filings by foreigners in a particular year relative to reform to the number of patent filinings by foreigners in the year prior to a reform and then selecting the median ratio across reforming countries. The Resident Patent Filings line display the index for resident patent filings.

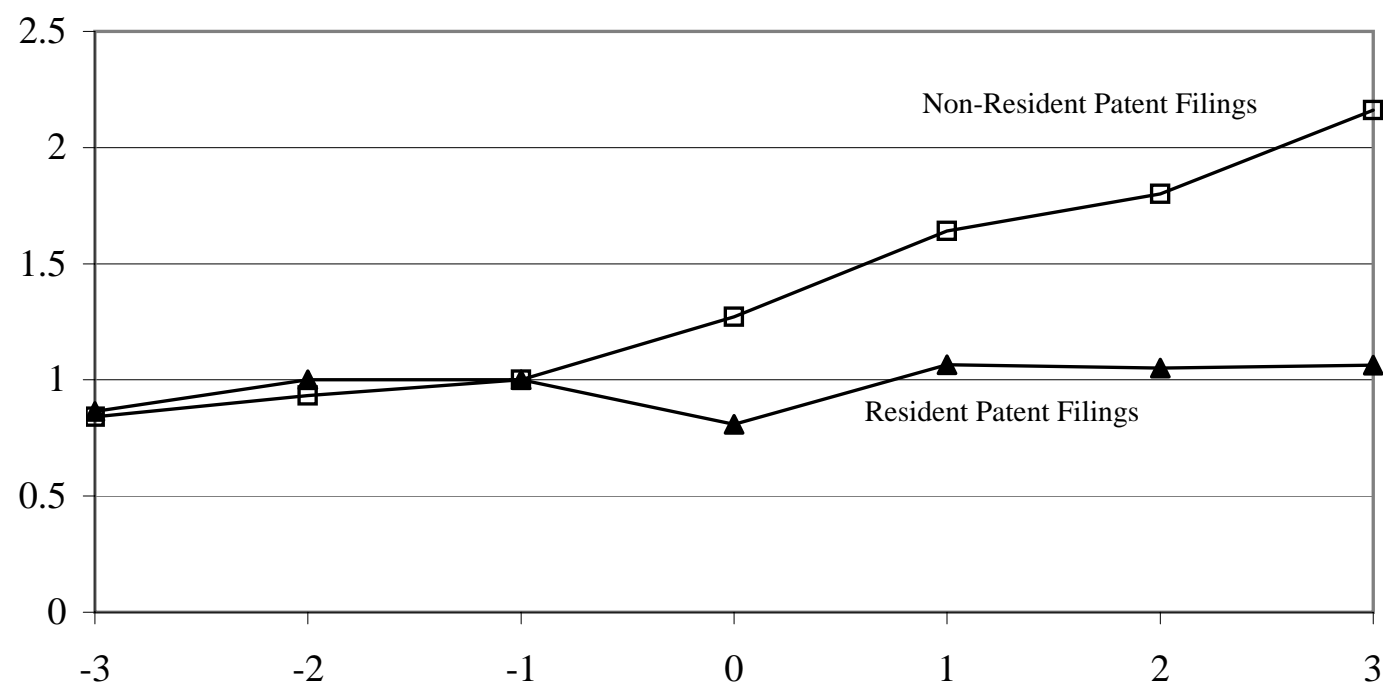

Year Relative to Reform 


\section{Table I}

\section{Descriptive Statistics for U.S. Multinational Activity in Reforming Countries}

The top panel provides descriptive statistics for the data obtained from BEA surveys and from WIPO. Intrafirm royalty payments are royalty payments made b: affiliates to their parents for the sale or use of intangible assets and like the other financial data are measured in thousands of dollars. Parent R\&D Expenditures are the R\&D expenditures of the domestic operations of the parent. In years for which these data are unavailable, R\&D expenditures for consolidated parent companies from COMPUSTAT are used. Parent System Sales are the total sales of the parent and its affiliates. Arms Length Royalty Payments are royalty payments made by unaffiliated foreign persons to U.S. persons that may or may not be parents of multinationals. The Number of Non-Resident Patent Filings and the Number of Resident Patent Filings are counts of patent applications by non-residents and residents in a particular country and year. The bottom panel provides descriptive statistics for the country level control variables that are used in the analysis. The Difference of Host Country Tax Rate and US Tax Rate is the difference between the corporate income tax rate in the host country and the US corporate income tax rate. The Host Country Tax Rate and the Hosi Country Withholding Tax Rate are annual median tax rates paid by affiliates in a host country. Host Country Inward FDI Restrictions is a dummy equal to one when inward FDI restrictions exist, and it is drawn from Brune (2001). Host Country Trade Openness is the index of constant price openness taken from Heston, Summers, and Aten (2002). The Log of Host Country GDP per capita and the Log of Host Country FDI are derived from data provided in the World Bank World Development Indicators (2003).

Number of Affiliates

Number of Parents

Intrafirm Royalty Payments

Mean

Standard Deviation

R\&D Expenditures

Mean

Standard Deviation

Sales

Mean

Standard Deviation

Parent R\&D Expenditures

Mean

Standard Deviation

Parent System Sales

Mean

Standard Deviation

Arms Length Royalty Payments

Mean

Standard Deviation

na

82,933

285,963

84,282

364,134

3,349,773

$4,013,461$

$4,293,810$

$13,307,540$

75,505

345,105

$9,728,727$

$11,648,800$

48

1,562

75

2,503

122

na

5,992

7,955

11,022

13,722

20,606

21,597

58,572

Standard Deviation

Number of Resident Patent Filings

Mean

Standard Deviation

27,183

74,236
33,511

99,849
$6,146,036$

$17,628,410$

\section{Descriptive Statistics for all Affiliate Years}

Difference of Host Country Tax Rate and US Tax Rate

Host Country Withholding Tax Rate

Host Country Inward FDI Restrictions

Host Country Trade Openness

Log of Host Country GDP per Capita

Log of Host Country FDI

\begin{tabular}{cccc} 
Mean & & St. Dev \\
\cline { 1 - 1 } 0.0268 & & 0.1328 \\
0.0670 & & 0.0823 \\
0.0778 & & 0.2678 \\
35.1122 & & 23.5311 \\
9.0308 & & 0.6962 \\
21.1733 & & 1.6761
\end{tabular}




\section{Table II}

\section{Timing of Major Patent Reforms}

This table provides information about the timing of reforms in the countries that strengthen their intellectual property rights and the number of reporting affiliates present in these countries at the beginning and end of the sample period.

\begin{tabular}{|c|c|c|c|}
\hline \multirow[t]{2}{*}{ Country } & \multirow[t]{2}{*}{$\begin{array}{l}\text { Year of } \\
\text { Reform }\end{array}$} & \multicolumn{2}{|c|}{$\begin{array}{c}\text { Number of Affiliates in } \\
\text { BEA database }\end{array}$} \\
\hline & & 1982 & 1999 \\
\hline Argentina & 1996 & 206 & 388 \\
\hline Brazil & 1997 & 601 & 596 \\
\hline China & 1993 & 11 & 522 \\
\hline Indonesia & 1991 & 143 & 169 \\
\hline Japan & 1995 & 704 & 928 \\
\hline South Korea & 1987 & 93 & 241 \\
\hline Mexico & 1991 & 702 & 927 \\
\hline The Philippines & 1997 & 186 & 163 \\
\hline Spain & 1986 & 362 & 569 \\
\hline Taiwan & 1993 & 118 & 235 \\
\hline Thailand & 1992 & 87 & 225 \\
\hline Turkey & 1995 & 27 & 116 \\
\hline
\end{tabular}




\section{Table III}

\section{Intrafirm Royalty Payments and IPR Regime Changes}

The dependent variable in the first three columns is the log of one plus the value of royalty payments made by affiliates to their parents, and the dependent variable in columns 4-6 is the log of one plus the ratio of intrafirm royalty payments to affiliate sales. The Post Reform Dummy is a dummy equal to one in the year of reform and in the years following the reforms identified in Table II. The High Patent Use Dummy is a dummy that is equal to one for affiliates of parents that over the four years prior to a reform average at least as many patent applications as the parents of the median affiliate in the reforming country. The Difference of Host Country Tax Rate and US Tax Rate is the difference between the corporate income tax rate in the host country and the US corporate income tax rate. The Host Country Tax Rate and the Host Country Withholding Tax Rate are annual median tax rates paid by affiliates in a host country. Host Country Inward FDI Restrictions is a dummy equal to one when inward FDI restrictions exist, and it is drawn from Brune (2001). Host Country Trade Openness is the index of constant price openness taken from Heston, Summers, and Aten (2002).

The Log of Host Country GDP per capita is derived from data provided in the World Bank World Development Indicators (2003). Log of Affiliate Sales is the log of the value of affiliate sales, and Log of Parent R\&D Expenditures is the log of the affiliate's parent R\&D expenditures. The Log of Parent System Sales is the log of total sales of the parent and its affiliates. All specifications include affiliate and year fixed effects as well as country specific time trends. Heteroskedasticity-consistent standard errors appear in parentheses.

\begin{tabular}{|c|c|c|c|c|c|c|}
\hline \multirow[t]{2}{*}{ Dependent Variable: } & \multicolumn{3}{|c|}{ Log of Intrafirm Royalty Payments } & \multicolumn{3}{|c|}{$\begin{array}{l}\text { Log of Intrafirm Royalty } \\
\text { Payments/Affiliate Sales }\end{array}$} \\
\hline & $(1)$ & $(2)$ & (3) & (4) & $(5)$ & $(6)$ \\
\hline Constant & $\begin{array}{r}22.5149 \\
(21.2651)\end{array}$ & $\begin{array}{r}22.1481 \\
(30.2057)\end{array}$ & $\begin{array}{r}62.5752 \\
(31.7866)\end{array}$ & $\begin{array}{r}0.1086 \\
(0.1140)\end{array}$ & $\begin{array}{r}0.1072 \\
(0.1559)\end{array}$ & $\begin{array}{r}0.1660 \\
(0.1619)\end{array}$ \\
\hline Post Reform Dummy & $\begin{array}{r}0.0980 \\
(0.0412)\end{array}$ & $\begin{array}{r}0.0199 \\
(0.0647)\end{array}$ & $\begin{array}{r}0.0247 \\
(0.0664)\end{array}$ & $\begin{array}{r}0.0008 \\
(0.0002)\end{array}$ & $\begin{array}{r}0.0005 \\
(0.0003)\end{array}$ & $\begin{array}{r}0.0006 \\
(0.0003)\end{array}$ \\
\hline $\begin{array}{l}\text { Post Reform Dummy * High Patent Use } \\
\text { Dummy }\end{array}$ & & $\begin{array}{r}0.2657 \\
(0.0715)\end{array}$ & $\begin{array}{r}0.2130 \\
(0.0732)\end{array}$ & & $\begin{array}{r}0.0012 \\
(0.0004)\end{array}$ & $\begin{array}{r}0.0011 \\
(0.0004)\end{array}$ \\
\hline $\begin{array}{l}\text { Difference of Host Country Tax Rate and } \\
\text { US Tax Rate }\end{array}$ & $\begin{array}{r}-0.0519 \\
(0.2458)\end{array}$ & $\begin{array}{r}-0.2144 \\
(0.3675)\end{array}$ & $\begin{array}{r}-0.2924 \\
(0.3782)\end{array}$ & $\begin{array}{r}-0.0005 \\
(0.0013)\end{array}$ & $\begin{array}{r}-0.0035 \\
(0.0018)\end{array}$ & $\begin{array}{r}-0.0038 \\
(0.0019)\end{array}$ \\
\hline Host Country Withholding Tax Rate & $\begin{array}{r}0.2077 \\
(0.3359)\end{array}$ & $\begin{array}{r}0.1078 \\
(0.4950)\end{array}$ & $\begin{array}{r}0.0699 \\
(0.5198)\end{array}$ & $\begin{array}{r}-0.0015 \\
(0.0018)\end{array}$ & $\begin{array}{r}-0.0060 \\
(0.0023)\end{array}$ & $\begin{array}{r}-0.0062 \\
(0.0024)\end{array}$ \\
\hline Host Country Inward FDI Restrictions & $\begin{array}{r}-0.1427 \\
(0.0672)\end{array}$ & $\begin{array}{r}-0.1108 \\
(0.1103)\end{array}$ & $\begin{array}{r}-0.1038 \\
(0.1103)\end{array}$ & $\begin{array}{r}-0.0003 \\
(0.0004)\end{array}$ & $\begin{array}{r}-0.0001 \\
(0.0006)\end{array}$ & $\begin{array}{r}-0.0001 \\
(0.0006)\end{array}$ \\
\hline Host Country Trade Openness & $\begin{array}{r}0.0063 \\
(0.0022)\end{array}$ & $\begin{array}{r}0.0050 \\
(0.0031)\end{array}$ & $\begin{array}{r}0.0038 \\
(0.0032)\end{array}$ & $\begin{array}{r}0.0000 \\
(0.0000)\end{array}$ & $\begin{array}{r}0.0000 \\
(0.0000)\end{array}$ & $\begin{array}{r}0.0000 \\
(0.0000)\end{array}$ \\
\hline Log of Host Country GDP per Capita & $\begin{array}{r}1.1022 \\
(0.1919)\end{array}$ & $\begin{array}{r}1.1045 \\
(0.2758)\end{array}$ & $\begin{array}{r}1.0772 \\
(0.2854)\end{array}$ & $\begin{array}{r}0.0028 \\
(0.0010)\end{array}$ & $\begin{array}{r}0.0032 \\
(0.0013)\end{array}$ & $\begin{array}{r}0.0035 \\
(0.0014)\end{array}$ \\
\hline Log of Affiliate Sales & & & $\begin{array}{r}0.0993 \\
(0.0130)\end{array}$ & & & \\
\hline Log of Parent R\&D Expenditures & & & $\begin{array}{r}0.0138 \\
(0.0103)\end{array}$ & & & $\begin{array}{r}0.0001 \\
(0.0000)\end{array}$ \\
\hline Log of Parent System Sales & & & $\begin{array}{r}0.3244 \\
(0.0678)\end{array}$ & & & $\begin{array}{r}0.0000 \\
(0.0003)\end{array}$ \\
\hline Affiliate and Year Fixed Effects? & $\mathrm{Y}$ & $\mathrm{Y}$ & $\mathrm{Y}$ & $\mathrm{Y}$ & $\mathrm{Y}$ & $\mathrm{Y}$ \\
\hline Country Specific Time Trends? & $\mathrm{Y}$ & $\mathrm{Y}$ & $\mathrm{Y}$ & $\mathrm{Y}$ & $\mathrm{Y}$ & Y \\
\hline $\begin{array}{l}\text { No. of Obs. } \\
\text { R-Squared }\end{array}$ & $\begin{array}{c}44,375 \\
0.7468\end{array}$ & $\begin{array}{c}16,998 \\
0.7261\end{array}$ & $\begin{array}{c}16,418 \\
0.7289\end{array}$ & $\begin{array}{c}42,387 \\
0.6739\end{array}$ & $\begin{array}{c}16,553 \\
0.6735\end{array}$ & $\begin{array}{c}16,038 \\
0.6764\end{array}$ \\
\hline
\end{tabular}




\section{Table IV}

\section{Affiliate R\&D Expenses and IPR Regime Changes}

The dependent variable in the first three columns is the log of one plus the value of affiliate R\&D expenditures, and the dependent variable in columns 4-6 is the log of one plus the ratio of affiliate R\&D expenditures to affiliate sales. The Post Reform Dummy is a dummy equal to one in the year of and the years following the reforms identified in Table II. The High Patent Use Dummy is a dummy that is equal to one for affiliates of parents that over the fours years prior to a reform average at least as many patent applications as the median affiliate in the reforming country. The Difference of Host Country Tax Rate and US Tax Rate is the difference between the corporate income tax rate in the host country and the US corporate income tax rate. The Host Country Tax Rate and the Host Country Withholding Tax Rate are annual median tax rates paid by affiliates in a host country. Host Country Inward FDI Restrictions is a dummy equal to one when inward FDI restrictions exist, and it is drawn from Brune (2001). Host Country Trade Openness is the index of constant price openness taken from Heston, Summers, and Aten (2002). The Log of Host Country GDP per capita is derived

is the log of the value of affiliate sales, and Log of Parent R\&D Expenditures is the log of the affiliate's parent R\&D expenditures. The Log of Parent System Sales is the log of total sales of the parent and its affiliates. All specifications include affiliate and year fixed effects as well as country specific time trends. Heteroskedasticity-consistent standard errors appear in parentheses.

\begin{tabular}{|c|c|c|c|c|c|c|}
\hline \multirow[t]{2}{*}{ Dependent Variable: } & \multicolumn{3}{|c|}{ Log of R\&D Expenditures } & \multicolumn{3}{|c|}{$\begin{array}{c}\text { Log of R\&D Expenditures/Affiliate } \\
\text { Sales }\end{array}$} \\
\hline & (1) & (2) & (3) & (4) & (5) & (6) \\
\hline Constant & $\begin{array}{r}14.1964 \\
(35.8392)\end{array}$ & $\begin{array}{r}92.9742 \\
(51.6872)\end{array}$ & $\begin{array}{l}104.2398 \\
(52.9545)\end{array}$ & $\begin{array}{r}-0.0516 \\
(0.1390)\end{array}$ & $\begin{array}{r}0.1424 \\
(0.1807)\end{array}$ & $\begin{array}{r}0.0819 \\
(0.1843)\end{array}$ \\
\hline Post Reform Dummy & $\begin{array}{r}0.1010 \\
(0.0590)\end{array}$ & $\begin{array}{r}-0.0144 \\
(0.0946)\end{array}$ & $\begin{array}{r}-0.0099 \\
(0.0949)\end{array}$ & $\begin{array}{r}-0.0004 \\
(0.0002)\end{array}$ & $\begin{array}{r}-0.0006 \\
(0.0004)\end{array}$ & $\begin{array}{r}-0.0006 \\
(0.0004)\end{array}$ \\
\hline $\begin{array}{l}\text { Post Reform Dummy * High Patent Use } \\
\text { Dummy }\end{array}$ & & $\begin{array}{r}0.3353 \\
(0.1020)\end{array}$ & $\begin{array}{r}0.2775 \\
(0.1026)\end{array}$ & & $\begin{array}{r}0.0009 \\
(0.0004)\end{array}$ & $\begin{array}{r}0.0009 \\
(0.0004)\end{array}$ \\
\hline $\begin{array}{l}\text { Difference of Host Country Tax Rate and } \\
\text { US Tax Rate }\end{array}$ & $\begin{array}{r}0.5095 \\
(0.4135)\end{array}$ & $\begin{array}{r}-0.1515 \\
(0.6082)\end{array}$ & $\begin{array}{r}-0.2776 \\
(0.6097)\end{array}$ & $\begin{array}{r}0.0039 \\
(0.0016)\end{array}$ & $\begin{array}{r}0.0018 \\
(0.0020)\end{array}$ & $\begin{array}{r}0.0017 \\
(0.0020)\end{array}$ \\
\hline Host Country Withholding Tax Rate & $\begin{array}{r}1.1866 \\
(0.5846)\end{array}$ & $\begin{array}{r}0.0313 \\
(0.8906)\end{array}$ & $\begin{array}{r}-0.0101 \\
(0.9068)\end{array}$ & $\begin{array}{r}0.0055 \\
(0.0021)\end{array}$ & $\begin{array}{r}0.0025 \\
(0.0028)\end{array}$ & $\begin{array}{r}0.0025 \\
(0.0028)\end{array}$ \\
\hline Host Country Inward FDI Restrictions & $\begin{array}{r}-0.1126 \\
(0.0901)\end{array}$ & $\begin{array}{r}-0.1832 \\
(0.1420)\end{array}$ & $\begin{array}{r}-0.1976 \\
(0.1409)\end{array}$ & $\begin{array}{r}-0.0003 \\
(0.0004)\end{array}$ & $\begin{array}{r}-0.0006 \\
(0.0005)\end{array}$ & $\begin{array}{r}-0.0006 \\
(0.0006)\end{array}$ \\
\hline Host Country Trade Openness & $\begin{array}{r}0.0049 \\
(0.0049)\end{array}$ & $\begin{array}{r}0.0127 \\
(0.0081)\end{array}$ & $\begin{array}{r}0.0138 \\
(0.0082)\end{array}$ & $\begin{array}{r}0.0000 \\
(0.0000)\end{array}$ & $\begin{array}{r}0.0001 \\
(0.0000)\end{array}$ & $\begin{array}{r}0.0001 \\
(0.0000)\end{array}$ \\
\hline Log of Host Country GDP per Capita & $\begin{array}{r}0.5103 \\
(0.3771)\end{array}$ & $\begin{array}{r}0.7723 \\
(0.5953)\end{array}$ & $\begin{array}{r}0.5534 \\
(0.6073)\end{array}$ & $\begin{array}{r}0.0010 \\
(0.0016)\end{array}$ & $\begin{array}{r}0.0011 \\
(0.0023)\end{array}$ & $\begin{array}{r}0.0012 \\
(0.0023)\end{array}$ \\
\hline Log of Affiliate Sales & & & $\begin{array}{r}0.1472 \\
(0.0184)\end{array}$ & & & \\
\hline Log of Parent R\&D Expenditures & & & $\begin{array}{r}0.0285 \\
(0.0150)\end{array}$ & & & $\begin{array}{r}0.0002 \\
(0.0001)\end{array}$ \\
\hline Log of Parent System Sales & & & $\begin{array}{r}0.0779 \\
(0.1061)\end{array}$ & & & $\begin{array}{r}-0.0007 \\
(0.0004)\end{array}$ \\
\hline Affiliate and Year Fixed Effects? & Y & $\mathrm{Y}$ & $\mathrm{Y}$ & $\mathrm{Y}$ & $\mathrm{Y}$ & $\mathrm{Y}$ \\
\hline Country Specific Time Trends? & Y & $\mathrm{Y}$ & $\mathrm{Y}$ & $\mathrm{Y}$ & Y & $\mathrm{Y}$ \\
\hline $\begin{array}{l}\text { No. of Obs. } \\
\text { R-Squared }\end{array}$ & $\begin{array}{c}26,654 \\
0.7370\end{array}$ & $\begin{array}{c}9,688 \\
0.6961\end{array}$ & $\begin{array}{c}9,623 \\
0.6983\end{array}$ & $\begin{array}{c}25,343 \\
0.6858\end{array}$ & $\begin{array}{c}9,369 \\
0.6749\end{array}$ & $\begin{array}{c}9,346 \\
0.6751\end{array}$ \\
\hline
\end{tabular}




\section{Table V}

\section{Arm's Length Royalty Payments and IPR Regime Changes}

The dependent variable in each specification is the log of one plus the value of royalty payments made by unaffiliated foreign persons to US firms for the sale or use of intangible assets. The Post Reform Dummy is a dummy equal to one in the year of and the years following the reforms identified in Table II. The Difference of Host Country Tax Rate and US Tax Rate is the difference between the corporate income tax rate in the host country and the US corporate income tax rate. The Host Country Tax Rate and the Host Country Withholding Tax Rate are annual median tax rates paid by affiliates in a host country. Host Country Inward FDI Restrictions is a dummy equal to one when inward FDI restrictions exist, and it is drawn from Brune (2001). Host Country Trade Openness is the index of constant price openness taken from Heston, Summers, and Aten (2002). The Log of Host Country GDP per capita is derived from data provided in the World Bank World Development Indicators (2003). All specifications include firm/country fixed effects as well as country specific time trends. Heteroskedasticity-consistent standard errors appear in parentheses.

Dependent Variable:

Constant

Post Reform Dummy

Difference of Host Country Tax Rate and US Tax Rate

Host Country Withholding Tax Rate

Host Country Inward FDI Restrictions

Host Country Trade Openness

Log of Host Country GDP per Capita

Parent/Country and Year Fixed Effects?

Country Specific Time Trend?

No. of Obs.

R-Squared
(1)

(2)

13.7093

97.0149

11.8042

(25.7812)

(99.3360)

(31.4634)

0.0454

0.0904

0.0592

(0.0261)

(0.1028)

(0.0292)

$-0.0389$

$-0.6281$

0.1346

(0.1670)

(0.6535)

(0.1978)

$\begin{array}{rrr}-1.0048 & -1.9413 & -0.7489 \\ (0.5452) & (1.9997) & (0.6592)\end{array}$

$-0.1451$

$-0.1782$

$-0.1405$

(0.0758)

(0.2386)

(0.0911)

$-0.0004$

0.0056

$-0.0019$

(0.0028)

(0.0134)

(0.0034)

0.4540

0.5724

0.5373

(0.2009)

(0.6856)

(0.2385)

$\begin{array}{lll}Y & Y & Y \\ Y & Y & Y\end{array}$

\begin{tabular}{ccc}
46,460 & 4,871 & 28,914 \\
0.7643 & 0.7642 & 0.7481 \\
\hline
\end{tabular}




\section{Table VI}

\section{Host Country Patenting Activity and IPR Regime Changes}

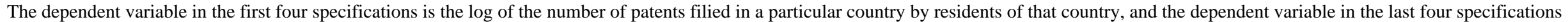

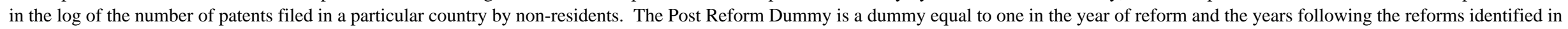

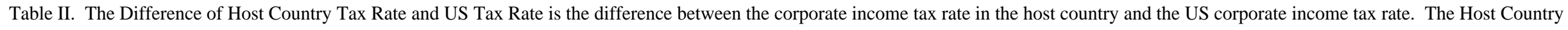

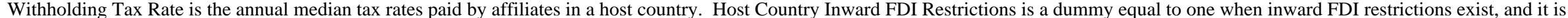

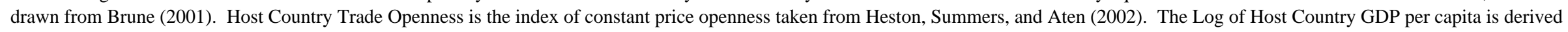

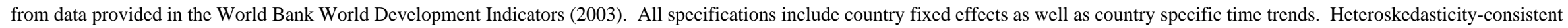
standard errors appear in parentheses.

\begin{tabular}{|c|c|c|c|c|c|c|c|c|}
\hline \multirow[t]{2}{*}{ Dependent Variable: } & \multicolumn{4}{|c|}{ Log of Resident Patent Filings } & \multicolumn{4}{|c|}{ Log of Non-Resident Patent Filiings } \\
\hline & (1) & $(2)$ & (3) & (4) & (5) & (6) & $(7)$ & $(8)$ \\
\hline Constant & $\begin{array}{r}7.0197 \\
(0.6487)\end{array}$ & $\begin{array}{r}20.7387 \\
(10.2948)\end{array}$ & $\begin{array}{r}6.6135 \\
(0.7204)\end{array}$ & $\begin{array}{c}19.7757 \\
(9.7460)\end{array}$ & $\begin{array}{r}7.8368 \\
(0.4270)\end{array}$ & $\begin{array}{r}-8.1660 \\
(6.8139)\end{array}$ & $\begin{array}{r}6.8564 \\
(0.5344)\end{array}$ & $\begin{array}{r}-4.1342 \\
(6.4278)\end{array}$ \\
\hline Post Reform Dummy & $\begin{array}{r}0.0183 \\
(0.2114)\end{array}$ & $\begin{array}{r}0.0800 \\
(0.2203)\end{array}$ & $\begin{array}{r}0.0792 \\
(0.2063)\end{array}$ & $\begin{array}{r}0.1605 \\
(0.2163)\end{array}$ & $\begin{array}{r}0.3841 \\
(0.1352)\end{array}$ & $\begin{array}{r}0.4257 \\
(0.1329)\end{array}$ & $\begin{array}{r}0.5435 \\
(0.1295)\end{array}$ & $\begin{array}{r}0.5881 \\
(0.1255)\end{array}$ \\
\hline Post Reform Dummy * Time Trend & & & $\begin{array}{r}0.1065 \\
(0.0962)\end{array}$ & $\begin{array}{r}0.1269 \\
(0.1012)\end{array}$ & & & $\begin{array}{r}0.2706 \\
(0.0690)\end{array}$ & $\begin{array}{r}0.2488 \\
(0.0679)\end{array}$ \\
\hline Host Country Withholding Tax Rate & $\begin{array}{r}-0.2781 \\
(1.4100)\end{array}$ & $\begin{array}{r}0.1048 \\
(1.3565)\end{array}$ & $\begin{array}{r}0.5517 \\
(1.4292)\end{array}$ & $\begin{array}{r}1.1393 \\
(1.4784)\end{array}$ & $\begin{array}{r}1.0122 \\
(0.8211)\end{array}$ & $\begin{array}{r}0.6577 \\
(0.7593)\end{array}$ & $\begin{array}{r}3.1513 \\
(0.9240)\end{array}$ & $\begin{array}{r}2.7043 \\
(0.9864)\end{array}$ \\
\hline Host Country Inward FDI Restrictions & $\begin{array}{r}0.7600 \\
(0.5375)\end{array}$ & $\begin{array}{r}0.8600 \\
(0.5554)\end{array}$ & $\begin{array}{r}0.7804 \\
(0.5331)\end{array}$ & $\begin{array}{r}0.9036 \\
(0.5474)\end{array}$ & $\begin{array}{r}0.0231 \\
(0.2130)\end{array}$ & $\begin{array}{r}-0.2307 \\
(0.1541)\end{array}$ & $\begin{array}{r}0.0742 \\
(0.2233)\end{array}$ & $\begin{array}{r}-0.1413 \\
(0.1651)\end{array}$ \\
\hline Host Country Trade Openness & $\begin{array}{r}0.0036 \\
(0.0153)\end{array}$ & $\begin{array}{r}0.0083 \\
(0.0161)\end{array}$ & $\begin{array}{r}0.0080 \\
(0.0160)\end{array}$ & $\begin{array}{r}0.0144 \\
(0.0170)\end{array}$ & $\begin{array}{r}0.0214 \\
(0.0120)\end{array}$ & $\begin{array}{r}0.0243 \\
(0.0076)\end{array}$ & $\begin{array}{r}0.0307 \\
(0.0126)\end{array}$ & $\begin{array}{r}0.0361 \\
(0.0082)\end{array}$ \\
\hline Log of Host Country GDP per Capita & & $\begin{array}{r}-1.3475 \\
(1.1136)\end{array}$ & & $\begin{array}{r}-1.6205 \\
(1.1458)\end{array}$ & & $\begin{array}{r}1.7457 \\
(0.7324)\end{array}$ & & $\begin{array}{r}1.1949 \\
(0.6941)\end{array}$ \\
\hline Log of Host Country FDI & & $\begin{array}{r}-0.0588 \\
(0.0565)\end{array}$ & & $\begin{array}{r}-0.0566 \\
(0.0549)\end{array}$ & & $\begin{array}{r}-0.0222 \\
(0.0404)\end{array}$ & & $\begin{array}{r}-0.0176 \\
(0.0368)\end{array}$ \\
\hline $\begin{array}{l}\text { Country and Year Fixed Effects? } \\
\text { Country Specific Time Trends? }\end{array}$ & $\begin{array}{l}\mathrm{Y} \\
\mathrm{Y}\end{array}$ & $\begin{array}{l}\mathrm{Y} \\
\mathrm{Y}\end{array}$ & $\begin{array}{l}\mathrm{Y} \\
\mathrm{Y}\end{array}$ & $\begin{array}{l}\mathrm{Y} \\
\mathrm{Y}\end{array}$ & $\begin{array}{l}\mathrm{Y} \\
\mathrm{Y}\end{array}$ & $\begin{array}{l}\mathrm{Y} \\
\mathrm{Y}\end{array}$ & $\begin{array}{l}\mathrm{Y} \\
\mathrm{Y}\end{array}$ & $\begin{array}{l}\mathrm{Y} \\
\mathrm{Y}\end{array}$ \\
\hline $\begin{array}{l}\text { No. of Obs. } \\
\text { R-Squared }\end{array}$ & $\begin{array}{c}160 \\
0.9545\end{array}$ & $\begin{array}{c}157 \\
0.9511\end{array}$ & $\begin{array}{c}160 \\
0.9548\end{array}$ & $\begin{array}{c}157 \\
0.9516\end{array}$ & $\begin{array}{c}163 \\
0.9618\end{array}$ & $\begin{array}{c}158 \\
0.9715\end{array}$ & $\begin{array}{c}163 \\
0.9672\end{array}$ & $\begin{array}{r}158 \\
0.9759\end{array}$ \\
\hline
\end{tabular}

